\title{
New sedimentological and palynological data from surface Miocene strata in the central Amazonas Basin area
}

\author{
Novos dados sedimentológicos e palinológicos de camadas \\ miocenas aflorantes na área central da Bacia do Amazonas \\ Emílio Alberto Amaral Soares ${ }^{1 *}$, Rodolfo Dino ${ }^{2,3}$, Dominicky Peres Soares ${ }^{1}$, \\ Luzia Antonioli ${ }^{3}$, Marco Antônio Lima da Silva ${ }^{4}$
}

\begin{abstract}
The scarcity of stratigraphic data has hindered the demarcation of the outcropping area of Miocene deposits of the Amazon Basin, represented informally by the Novo Remanso Formation. Moreover, this unit is characterized by a sparse and irregular geographic distribution due to its sedimentological features and rare fossil content. Miocene deposits cropping out in central Amazonas Basin area were described in sedimentological terms and analyzed palynologically. All analyses were undertaken in samples collected at the Uatumã River banks (Itapiranga and São Sebastião do Uatumã cities). Lithostratigraphic data shows that Novo Remanso Formation consists of sandstones, with subordinate conglomerates and pelites, characteristic of a meandering fluvial paleosystem, with fluvial channel, point bar, floodplain and crevasse splay facies. The palynoflora retrieved from five samples consists exclusively of continental-origin palynomorphs dominated by angiosperms species. Trilete spores are well represented, while gymnosperms pollen grains are minor components. The presence of Psilastephanoporites tesseroporus, Syncolporites poricostatus, Jandufouria seamrogiformis and Polypodiaceoisporites potoniei ensure these deposits fits into the Grimsdalea magnaclavata palynozone (Regali et al. $1974 \mathrm{a}, \mathrm{b})$, and the Grimsdalea magnaclavata/Crassoretitriletes vanraadshooveni palynozones of Jaramillo et al. (2011) considered Middle Miocene age. This age is confirmed by the zonation of Jaramillo et al. (2011), based on the LADs of Bombacacidites baumfalki (11.57Ma) and Crototricolpites annemariae $(12.91 \mathrm{Ma})$; and the FAD of Psilastephanoporites tesseroporus $(14.00 \mathrm{Ma})$. With these new data presented herein, it is possible to assume that the Miocene strata represented by the Novo Remanso Formation covers a larger area in the basin than previously considered, and that it may be extended for about $300 \mathrm{~km}$ until the Manacapuru village, indicating a Miocene subsidence phase. KEYWORDS: Novo Remanso Formation; Miocene; Amazonas Basin; Northern Brazil Basins.
\end{abstract}

RESUMO: A escassez de dados estratigráficos tem dificultado a delimitação da área aflorante dos depósitos miocenos da Bacia do Amazonas, representados informalmente pela Formação Novo Remanso. Ademais, essa unidade caracteriza-se por uma distribuição geográfica esparsa e irregular, dada suas características sedimentológicas e raro conteúdo fóssil. Estudos litoestratigráficos e palinológicos ora realizados em afloramentos do Rio Uatumá permitiram identificar a ocorrência dessa formação no limite dos municípios de Itapiranga e São Sebastiāo do Uatumã. Dados litoestratigráficos revelam que a Formação Novo Remanso consiste dominantemente de arenitos, com conglomerados e pelitos subordinados, característicos de um paleosistema fluvial meandrante, com fácies de canal, barra em pontal, planície de inundação e crevasse play. A palinoflora recuperada de cinco amostras é composta exclusivamente por palinomorfos de origem continental. O predominio é de espécies afins às angiospermas. Esporos triletes estão bem representados, enquanto os grãos de pólen gimnospérmicos são componentes menores na associação. A presença das espécies Psilastephanoporites tesseroporus, Syncolporites poricostatus, Jandufouria seamrogiformis e Polypodiaceoisporites potoniei assegura que esses depósitos se enquadram na palinozona Grimsdalea magnaclavata (Regali et al. 1974a, 1974b) e nas palinozonas Grimsdalea magnaclavata /Crassoretitriletes vanraadshooveni de Jaramillo et al. (2011), de idade Mioceno Médio. Dados de Jaramillo et al. (2011) confirmam essa idade, com base nas LADs das espécies Bombacacidites baumfalki (11.57 Ma) e Crototricolpites annemariae (12.91 Ma); e FAD de Psilastephanoporites tesseroporus $(14.00 \mathrm{Ma})$. Esses novos dados ampliam as informaçôes exaradas por Dino et al. (2012) sobre a Formação Novo Remanso e ratificam que as camadas miocenas cobrem uma área bem maior que a previamente considerada, podendo estender-se por cerca de $300 \mathrm{~km}$ até 0 município de Manacapuru.

PALAVRAS-CHAVE: Formação Novo Remanso; Amazonas; Bacias do Norte do Brasil.

\footnotetext{
${ }^{1}$ Institute of Exact Sciences, Department of Geosciences, Universidade Federal do Amazonas - UFAM, Manaus (AM), Brasil. E-mail: easoares@ufam.edu.br ${ }^{2}$ Petrobras/CENPES/PDEDS/AMA, Rio de Janeiro (RJ), Brasil. E-mail: dino@petrobras.com.br ${ }^{3}$ Department of Stratigraphy and Paleontology, Universidade do Estado do Rio de Janeiro - UERJ, Rio de Janeiro (RJ), Brasil. E-mail: luziaa@uerj.br ${ }^{4}$ Secretaria Municipal de Cultura do Município de Presidente Figueiredo - SEMUC, Amazonas (AM), Brasil. E-mail: cavernamarco@gmail.com *Corresponding author.
}

Manuscript ID: 30283. Received in: 04/16/2015. Approved in: 08/21/2015. 


\section{INTRODUCTION}

The current stratigraphic framework of the Amazonas Basin, proposed by Cunha et al. (2007), comprises two first order megasequences, one Paleozoic and the other MesozoicCenozoic. While the Paleozoic sequence has been object of numerous studies, due to its interest by the oil industry, the Mesozoic-Cenozoic (Javari Group) still lacks detailed lithostratigraphic/geochronological data aiming at the individualization of its constituent units. This sequence is represented mainly by the Cretaceous unit (Alter do Chão Formation), which extends uniformly throughout the basin and exhibits maximum thickness of 1,250 m. The Cenozoic sedimentary record, with a maximum thickness of $200 \mathrm{~m}$ (Cunha et al. 2007), has been assigned to the strata of the Solimóes and Marajó formations, occurring restrictedly nearby Purus and Gurupá arches, respectively. However, these formations belong to the stratigraphic framework of the Solimóes and Marajó basins, and their occurrence in the Amazon Basin has been questioned.

Only since 2000, stratigraphic, sedimentological and sedimentary facies studies (Rozo 2004, Soares 2007, Soares et al. 2010) allowed the individualization of post-Cretaceous sediments in outcrops along the Solimóes-Amazonas river system in the area between Manacapuru and Itacoatiara, central portion of the Amazon Basin. These deposits occur unconformably on top of the Alter do Chão Formation, being marked at the base and at the top by lateritic paleosols, and they have been informally termed Novo Remanso Formation, according to the homonymous locality east of Manaus. The age of this unit was determined by Dino et al. (2012) based on two sites studied in the city of Manacapuru, and this age can be positioned unambiguously in the Middle Miocene. As this is a new lithostratigraphic unit of the Amazon Basin, with restricted occurrence in the central portion of the basin, regional distribution of this formation has not yet been well defined in regional geological maps (CPRM 2006, 2008). However, additional geological and subsurface geophysical data (boreholes) confirmed the continued presence of this sedimentary cover for ca. $180 \mathrm{~km}$ between Manaus and Itacoatiara (Costa 2002, Andrade \& Soares 2009).

This study describes for the first time, based on sedimentary facies, stratigraphic and palynological data, the occurrence of fluvial Miocene deposits in the middle and lower sections of Uatumã River (Itapiranga and São Sebastião do Uatumá municipalities boundaries) (Fig. 1). The deposits are mainly sandstones with conglomerates and subordinate pelites, and to the north are in direct contact with the Paleozoic rocks of the northern edge of the Amazon Basin. Identifying Miocene deposits in this section of the Uatumã River enables us to enlarge the area of occurrence of this unit for about $300 \mathrm{~km}$ until Manacapuru, emphasizing a subsidence phase of the Amazon Basin during this period.

The determination of the age of this unit was based on spore-pollen recovered material composed exclusively of continental palynomorphs in which the presence of the species Psilastephanoporites tesseroporus, Bombacacidites baumfalki and Crototricolpites annemariae allowed us to constraint these deposits, according to Jaramillo et al. (2011) at Middle Miocene age (14.00 to $11.57 \mathrm{Ma}$ ).

\section{STUDY AREA}

This study focused on 11 outcrops continuously exposed in the middle and lower sections of the Uatumã River, which border the municipalities of Itapiranga and São Sebastiáo do Uatumã (Fig. 1, Tab. 1). The deposits are of Miocene age, and we performed stratigraphic, sedimentary and palynological analyses. The access to the area was through BR-174 and AM-240 roads and a secondary road (Ramal da Morena), but mainly through the river Uatumã, which allowed better access to the studied outcrops in the months of October and November (2011 and 2012, during the low water level season of the rivers.

\section{MATERIALS AND METHODS}

The characterization of Miocene deposits in outcrops on the banks of the Uatumã River (Fig. 2) covered stratigraphic, sedimentary facies and palynological analysis. The facies analysis was based on determination of the geometry, particle size, texture, sedimentary structures and paleocurrent patterns following the concepts of Walker (1992, 2006). The geological mapping of the unit through a section of about $25 \mathrm{~km}$ along the river relied primarily on developing columnar profiles and panoramic sections. These were prepared from photomosaics following Wisevich (1991).

Gray material with evident organic content was found within the upper and lower limits of a continuous layer of laminated pelite (P-01, P-07 and P-08 sites) (Figs. 3 to 5), where samples were collected for palynological analysis. Furthermore, for sedimentological purpose, P-02, P-03, P-05 and P-09 sites were sampled. Of all samples, 50\% proved to be palynologically fertile, containing fairly well preserved continental palynomorphs. Appendix I provides information about the collected samples, including number of samples and preparations, sampling levels, lithology, represented Formation and main palynomorphs identified with their respective positions on the slides. The release and concentration of palynomorphs in the samples followed 
conventional laboratory procedures (e.g. Phipps \& Playford 1984; Wood et al. 1996); the technique, briefly, involves the following steps:

1. physical degradation of about $60 \mathrm{~g}$ of pre-sterilized samples into small pieces (1-3 mm diameter),

2. removal of carbonates by the addition of diluted hydrochloric acid (20\%), all the samples had very low content of carbonates,

3. dissolution of the silicates by immersion in concentrated hydrofluoric acid (70\%),
4. removal of remaining fluorsilicates using hot hydrochloric acid 50\%,

5. careful and controlled oxidation with concentrated nitric acid for 5-10 minutes,

6. concentration of palynomorphs via heavy liquid $\left(\mathrm{ZnCl}_{2}\right.$ solution - density 2.0). After each step, the residue was neutralized with distilled $\mathrm{H}_{2} \mathrm{O}$, proceeding to the next stage.

The final residue was mounted on individual slides, and three slides were prepared per sample.

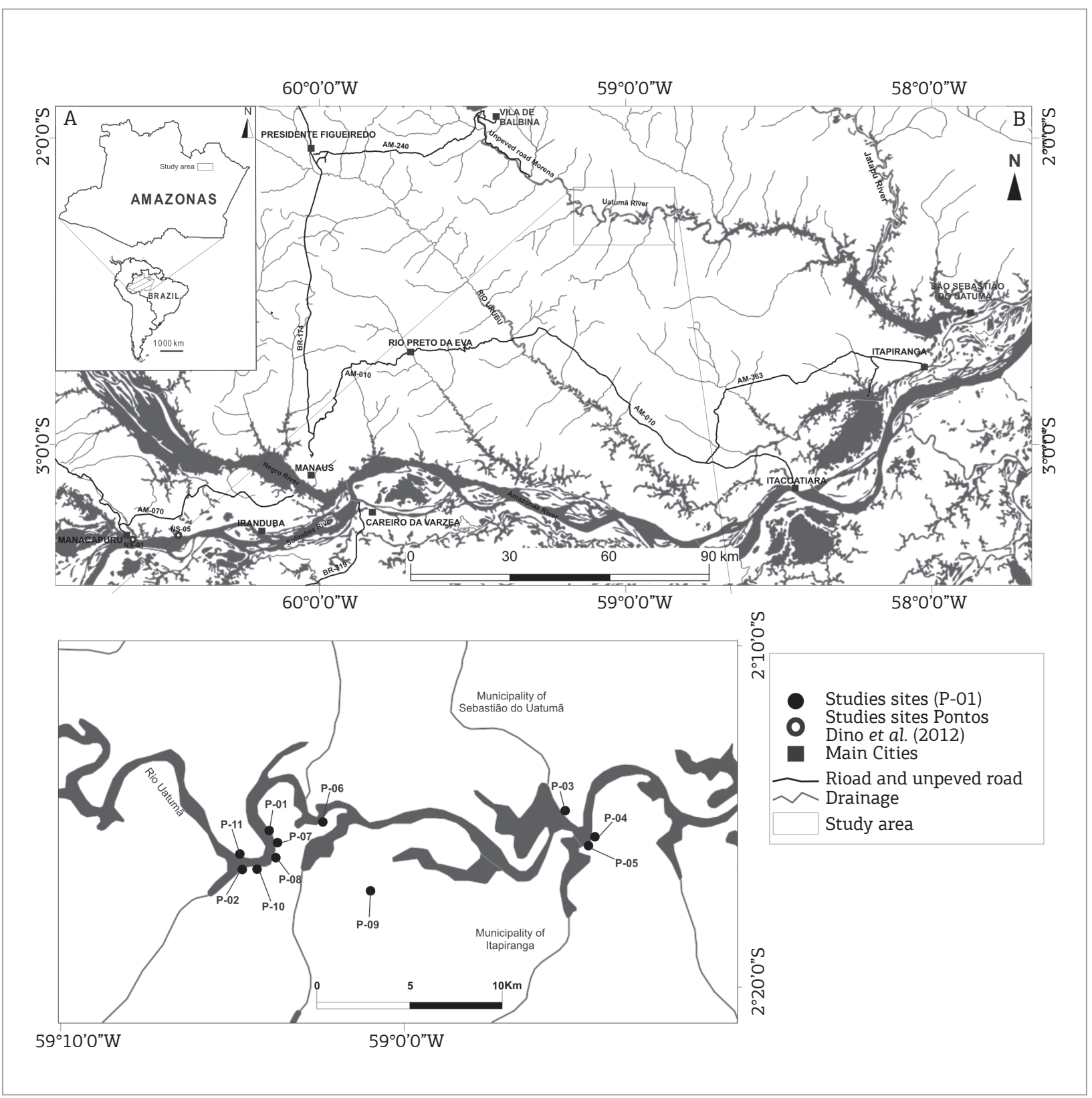

Figure 1. Amazonas State map with the studied area location (detail A). Detail showing the sampled points in the Rio Uatumã mid to lower stretch (detail B). 
The slides were scrutinized in detail and the representative palynomorphs of age and environment were captured by a Zeiss MC 80 DX camera attached to a Zeiss Axioplan microscope from the Department of Stratigraphy and Paleontology, Faculty of Geology, Universidade do Estado do Rio de Janeiro (UERJ), where the slides are cataloged and stored under the notations UT-01, UT-02, UT-03, UT-04, UT-12, UT-14, UT-17, UT-18 and UT-19.

\section{GEOLOGICAL AND PALEONTOLOGICAL CONTEXT OF PALEOGENE-NEOGENE SEDIMENTARY UNITS OF THE AMAZONAS BASIN}

\section{Stratigraphic and nomenclatural aspects}

By the end of the last century, Cenozoic units did not use to be individualized in the geological maps of the Amazonas Basin, and the entire post-Paleozoic sedimentary cover was generally assigned to the Alter do Chão Formation (Cretaceous). This was also the case of the sedimentary fill of tectonic depressions (grabens) developed over the Paleozoic basement on the northern edge of the basin in the region of Presidente Figueiredo (Nogueira et al. 1997).

Defining post-Cretaceous sedimentary units (Neogene and/or Paleogene) in the Amazonas Basin has been difficult due to the lack of systematic geological and paleontological studies, due mainly to the sandy and oxidized character of the deposits, which result in poor fossil potential. Pioneering studies by Mendes (1957) and Price (1960) "hypothetically" limited units of Pliocene (?) overlaid on the Cretaceous unit in boreholes in the regions of Alter do Chão (Pará) and Nova Olinda (Amazonas), with thicknesses around 500 and $170 \mathrm{~m}$, respectively, related to the "Série Barreiras". Palynological data obtained from surveys of the basins of northern Brazil (Acre, Solimóes, Amazonas and Marajó) allowed the individualization of tertiary units within the XVIII range defined by Daemon and Contreiras (1971). These units were included in the Cretaceous-Tertiary sequence defined for the Alter do Chão Formation (Travassos \& Barbosa Filho 1990, Cunha et al. 1994). The current stratigraphic chart of the basin (Cunha et al. 2007) individualizes Cenozoic deposits related to the Solimóes and Marajó formations, occurring restrictedly nearby the Purus and Gurupá arches, respectively. In the western portion of the basin, Caputo (1984) defined tertiary deposits assigned to the Almerim Formation on the 2-AL-1-AM hole (Petrobras).

Geological and geophysical studies of boreholes (Costa 2002, Andrade \& Soares 2009) defined an extensive Neogene sedimentary cover that extends for about $260 \mathrm{~km}$ between Manaus and Itacoatiara (central portion of the Amazon Basin) and presents a thickness of about $80 \mathrm{~m}$. In this region, outcrops of probable Miocene age were also described on the

Table 1. Analyzed outcrops coordinates.

\begin{tabular}{l|c|c|c|c}
\hline \multirow{2}{*}{ Outcrops studied } & \multirow{2}{*}{ Samples code } & \multicolumn{2}{|c|}{ Coordinates (UTM) } & Palynological \\
samples
\end{tabular}


banks of the Solimóes-Amazonas fluvial system (Rozo 2004, Soares et al. 2010, Gonçalves Júnior 2013), limited on the base and on the top by lateritic paleosols and overlying the Cretaceous unit. However, these studies did not present any dating, and the Miocene chronostratigraphic position was based solely on the correlation of lateritic paleosols limiting those deposits, as defined in eastern Amazonia by Kotschoubey and Truckenbrodt (1981), Costa (1991), Rossetti (2001) and Rossetti et al. (2013). In the region of Itacoatiara, this unit has about $10 \mathrm{~m}$ of outcrop thickness, consisting of coarse to fine ferruginous sandstones, with cross-tabular stratification and interbedded mudstones, representing channel and floodplain deposits related to a meandering fluvial paleosystem (Rozo, 2004). The informal designation of Novo Remanso Formation was assigned by Rozo et al. (2005) due to its occurrence in the homonymous locality southwest of Itacoatiara.

Soares (2007), studying Novo Remanso Formation outcrops in Manacapuru, proposed a subdivision in the upper and lower units according to three levels of lateritic paleossols described at the base, the intermediate portion and the top. This subdivision was adopted by Dino et al. (2012), who dated the upper section positioning it unequivocally in the Middle Miocene, while the lower section can be extended to the Lower Miocene. According to these studies, the formation consists mainly of sandstones, with pelites and conglomerates, representing channel deposits, point bars and floodplain of a meandering fluvial paleosystem.

The lithostratigraphic formalization of Novo Remanso Formation has not been well established. However, the nomenclature has been adopted in regional geological studies of Central Amazonia. In the CPRM map (2008), large areas attributed to Miocene sedimentary cover stretch between Manaus, Nova Olinda do Norte, Boa Vista de Ramos and Urucará, and were demarcated (acronym N12 nr) totaling dozens of kilometers.

In recent studies, Caputo $(2009,2011)$ proposed changes in the post-Paleozoic lithostratigraphic nomenclature of the Amazonas Basin. Based on existing paleobotanical, palynological and geophysical studies of the basin, the author accepted an extensive Tertiary sedimentary cover along its entire length, calling it "Alter do Chão Formation", overlying the Cretaceous unit that was called "Jazigo da Fazendinha Formation".

\section{LITHOFACIES}

\section{General aspects}

In general, the profiles studied in Rio Uatumã exhibit altered outcrop thickness of 10 to $15 \mathrm{~m}$, it is not possible to observe the lower limit with the underlying Paleozoic units.
Sometimes, they display whitish sandy soils (Spodosols), quartz and friable, with organic material disseminated and variable thickness (Fig. 2). Spodosols have been described in several places between Manaus and Presidente Figueiredo, being formed on the deposits of the Alter do Chão Formation (Horbe et al. 2003, 2004).

The studied profiles contain mainly sandstones with conglomerates and subordinate pelites arranged in layers that extend for dozens of meters. Five distinct sedimentary facies were identified (conglomeratic sandstone - Ac, sandstone with trough cross-bedding - Aa, tabular cross-bedding sandstone - At, massive sandstone - Am, and laminated pelite $-\mathrm{Pl})$, which are discussed according to the classification of Miall $(1985,1996)$ (Figs. 3 to 5, Tab. 2).

\section{Pebbly Sandstone - Ac}

Description - This facies is formed of conglomerate of whitish to yellowish coloring with massive aspect. It displays granules and pebbles of quartz and clay, poorly selected, measuring between $2-8 \mathrm{~cm}$, ranging from sub-angular to rounded, slightly spherical and without preferential orientation, supported by a medium to coarse grain size quartz sandstone matrix, moderately selected. The layers present $5-60 \mathrm{~cm}$ thickness and are sometimes coarsening upward, being overlapped and underlapped by the Am, Aa, At and Pl facies through sharp contacts (Figs. 3 to 5, Tab. 2 ).

\section{Sandstone With Trough Cross-Bedding - Aa}

Description - This facies is composed of whitish sandstone, a little clayey (kaolinic), with poorly sorted grains, which vary from sub-angular and sub-rounded, thin to coarse, with granules (quartz, feldspar and clay) from 1 to $3 \mathrm{~cm}$ in diameter, dispersed in layers. It also displays medium to large sandstone with trough cross-bedding, segregation of grains and granules within the limits of sets and foresets. This facies usually occurs in compound sets of tabular layers with thickness ranging from 1 to 2 meters. The Aa facies occurs underlapping the Ac facies, not being possible to observe the lower limit (Figs. 3 to 5, Tab. 2).

\section{Tabular Cross-Bedding Sandstone - At}

Description - The At facies consists of whitish sandstone of medium to coarse grain size, with poorly sorted grains ranging from sub-angular and sub-rounded, thin to thick, with dispersed granules. It displays tabular cross-bedding stratification of small to medium size, with segregation of grains and granules in foresets (Fig. 4, Tab. 1). This facies often occurs in individual tabular layers (sets) with a thickness ranging from 10 to $50 \mathrm{~cm}$, which form cosets of up to $6 \mathrm{~m}$ thick. It presents sharp lower contact with Am facies and Spodosols development on top. 


\section{Massive Sandstone - Am}

Description - This facies is composed of whitish to pinkish sandstone, poorly sorted, fine to coarse particle size, containing scattered quartz granules (Figs. 3 and 4, Tab. 1). It features a massive aspect and sometimes displays silicified portions with individual layers ranging from $3 \mathrm{~cm}$ to about $3 \mathrm{~m}$. This facies exhibit mildly undulating contact with underlapped $\mathrm{Pl}$ facies and straight contacts with At and Ac underlapped and overlapped facies.

\section{Laminated Pelite - P1}

Description - This facies is defined by medium brown to medium gray colour pelite, with plane-parallel lamination. It usually occurs on individual tabular layers with a thickness of up to $2 \mathrm{~m}$ and sometimes intercalated to centimetric layers of thin massive sandstone (Am facies) (Figs. 3 to 5, Tab. 1). In the bedding planes, it displays disseminated sulfides crystals.

\section{COMPOSITION, AGE AND ENVIRONMENTAL CHARACTERISTICS OF THE PALYNOFLORA}

Despite currently being the best elements for dating and correlation of continental strata of Brazilian Cenozoic basins, by allowing correspondence with the coeval marine strata of the continental margin basins, palynological studies carried out on Tertiary sections (PaleogeneNeogene) of the Amazonas Basin are extremely rare and mainly restricted to studies by Daemon and Contreiras (1971) and Dino et al. (2006, 2012). Palynological studies have been important in other regions of Amazonia and tropical South America including Van der Hammen (1957a, 1957b), Van der Hammen and Wijmstra (1964), Leidelmeyer (1966), Germeraad et al. (1968), Wijmstra (1971), Regali et al. (1974a, 1974b), Dueñas (1980), Lorente (1986), Müller et al. (1987), Hoorn (1993, 1994a, 1994b, 1994c), Leite et al. (1997), Jaramillo and Dilcher (2000, 2001), Pardo-Trujillo et al. (2003), Helenes and Cabrera (2003), Silva (2004, 2008), Leite (2007), Jaramillo et al. (2007, 2011) and Da SilvaCaminha et al. (2010).

This remarkable difference in terms of number of publications most likely occurs due to the scarcity of productive horizons, the difficulty in locating these levels and unfavorable conditions for the preservation of palynomorphs given the dominant depositional paleoenvironments during the sedimentation of the Tertiary layers on the Amazonas basin. Combined with this, the current pedogenic processes in a hot and humid climate which alter and modify the exposed rock hinder the preservation of its fossils constituents.

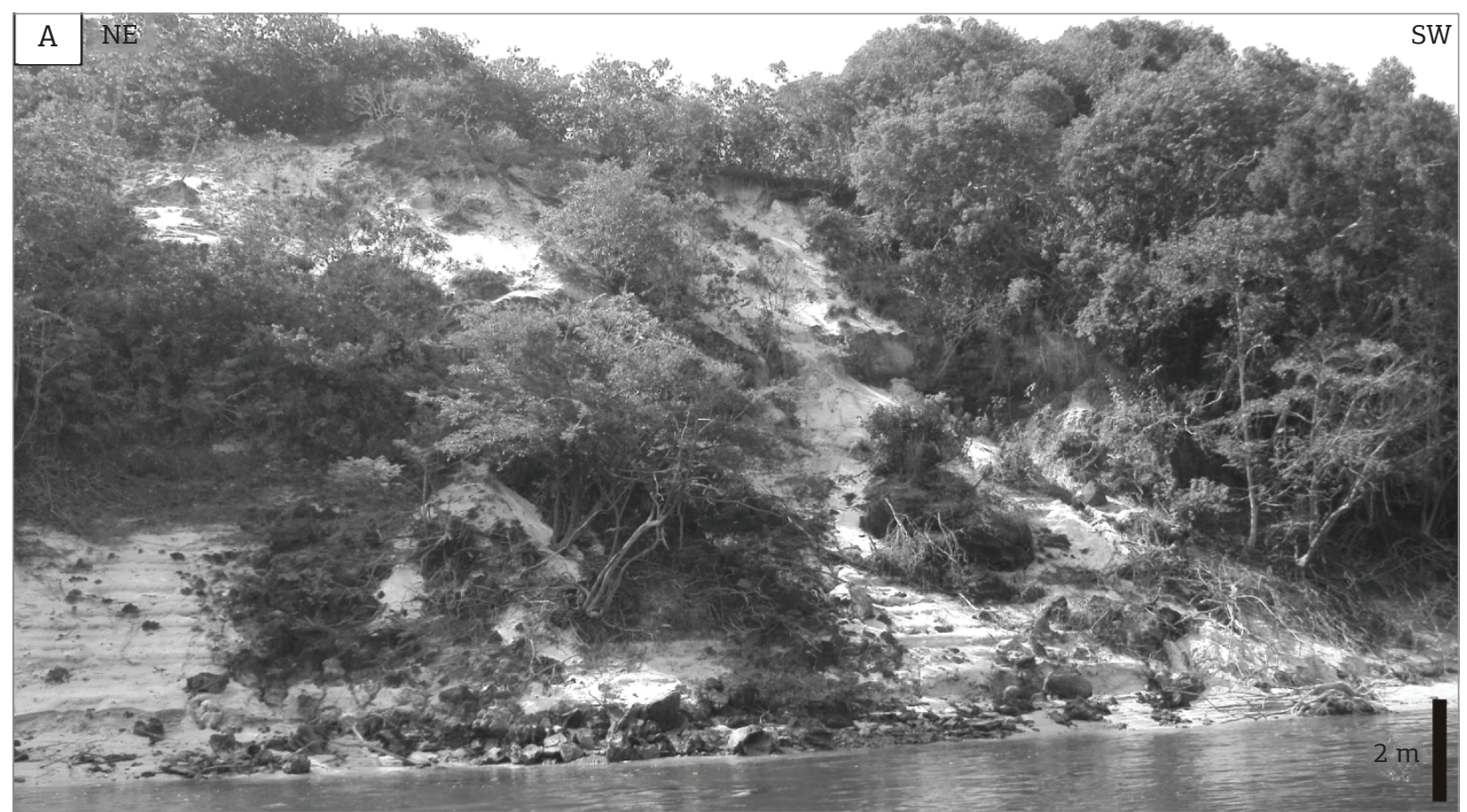

Figure 2. Spodosols developed on Novo Remanso Formation, Rio Uatumã left bank (locality UT-04). 
Table 2. Characteristics of the Novo Remanso Formation main lithofacies.

\begin{tabular}{|c|c|c|c|}
\hline Unit & Facies & Description & $\begin{array}{l}\text { Interpretation } \\
\text { Occurrence sites }\end{array}$ \\
\hline \multirow{5}{*}{ 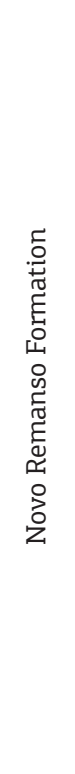 } & $\begin{array}{l}\text { Pebbly Sandstone } \\
\text { (Ac) }\end{array}$ & $\begin{array}{l}\text { Pebbly Sandstone with granules and pebbles of } \\
\text { quartz and clay supported by medium to coarse } \\
\text { grain size quartz sandstone matrix. Displays tabular } \\
\text { to lenticular geometry and massive aspect. }\end{array}$ & $\begin{array}{l}\text { Bed load deposition on fluvial channel } \\
\text { base. } \\
\text { Sites: P-01, P-07 e P-08. }\end{array}$ \\
\hline & $\begin{array}{l}\text { Trough cross- } \\
\text { bedding } \\
\text { sandstone } \\
\text { (Aa) }\end{array}$ & $\begin{array}{l}\text { Whitish sandstone, kaolinic, poorly sorted, thin to } \\
\text { coarse grains size, and dispersed granules. Displays } \\
\text { trough cross-bedding sandstone, and segregation } \\
\text { of grains and granules within the limits of sets and } \\
\text { foresets. }\end{array}$ & $\begin{array}{c}\text { Formed by migration of bars or dunes of } \\
\text { sinuous ridges by unidirectional flows in a } \\
\text { lower flow regime. } \\
\text { Sites: P-01, P-02, P-05, P-10 e P-18. }\end{array}$ \\
\hline & $\begin{array}{l}\text { Tabular } \\
\text { cross-bedding } \\
\text { sandstone } \\
\text { (At) }\end{array}$ & $\begin{array}{l}\text { Poorly sorted whitish sandstone with intermediate } \\
\text { to coarse grains size, and segregation of grains and } \\
\text { granules within the foresets. Displays tabular cross- } \\
\text { bedding stratification. }\end{array}$ & $\begin{array}{l}\text { Formed by migration of straight ridges } \\
\text { bars in a lower flow regime. } \\
\text { Sites: P-08, P-10 e P-18. }\end{array}$ \\
\hline & $\begin{array}{l}\text { Massive } \\
\text { sandstone } \\
\text { (Am) }\end{array}$ & $\begin{array}{l}\text { Whitish to pinkish sandstone, poorly sorted, fine } \\
\text { to coarse particle size, containing scattered quartz } \\
\text { granules. Exhibit massive aspect. }\end{array}$ & $\begin{array}{l}\text { Rapid deposition without enough time to } \\
\text { form sedimentary structures. } \\
\text { Sites: P-04, P-05, P-07, P-08, P-09, P-10. }\end{array}$ \\
\hline & $\begin{array}{l}\text { Laminated pelite } \\
\qquad(\mathrm{Pl})\end{array}$ & $\begin{array}{l}\text { Medium brown to medium gray pelite, with plane- } \\
\text { parallel lamination and present disseminated } \\
\text { sulphides crystals. Sometimes occurs intercalated } \\
\text { with Am facies. }\end{array}$ & $\begin{array}{l}\text { Thin material deposition from the } \\
\text { suspension process. } \\
\text { The interbedded of Am facies can be } \\
\text { associated with crevasse splay deposits. } \\
\text { Sites: P-01, P-07, P-08 e P-10. }\end{array}$ \\
\hline
\end{tabular}

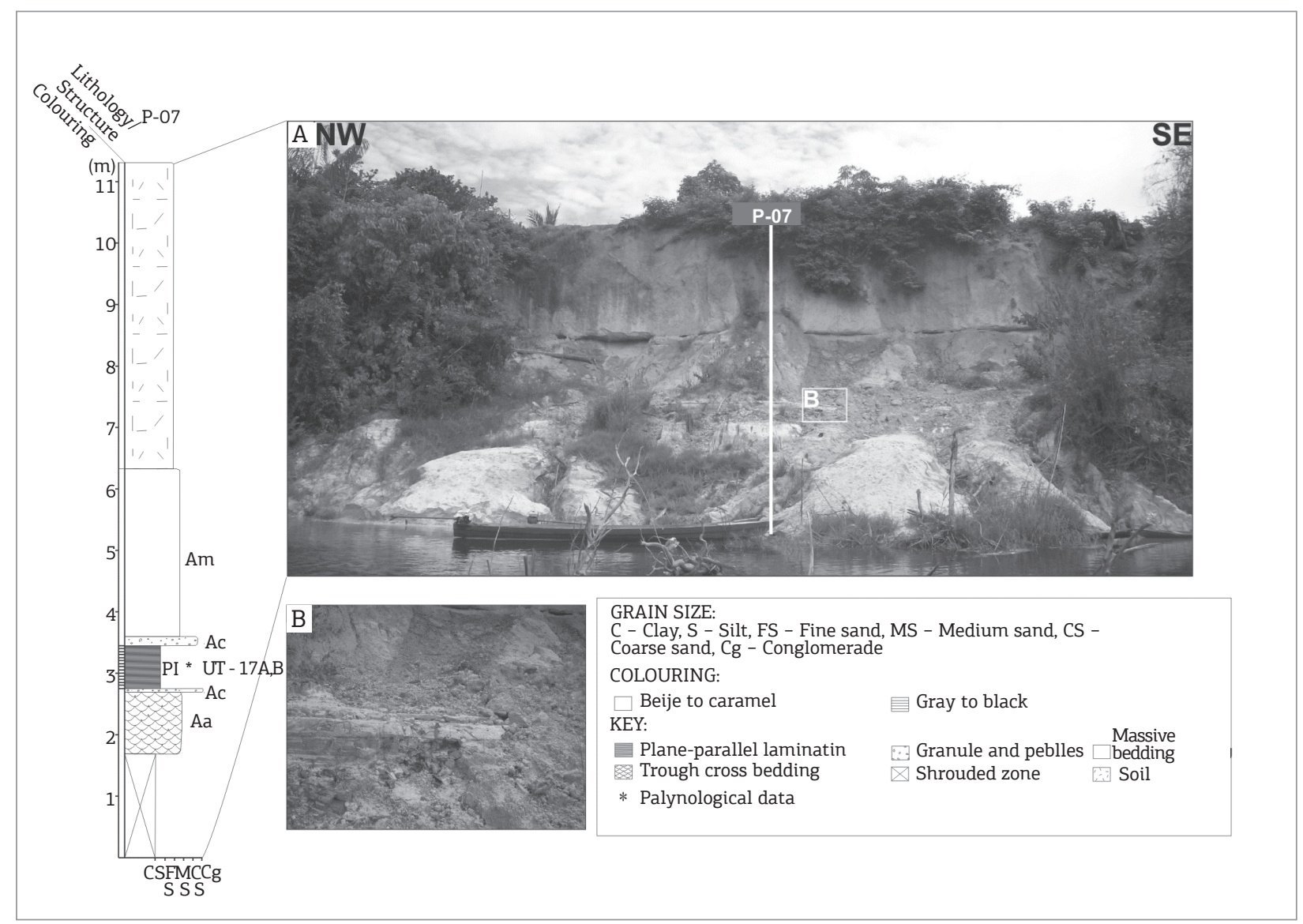

Figure 3. Outcrop panoramic and columnar sections (P-07 locality) on the Uatumã River right bank (detail A). The detail B shows the laminated pelite layer with samples locations. Aa, Ac, $\mathrm{Pl}$ and Am correspond to the sedimentary facies. 
Regardless of these adverse conditions, an extensive fieldwork is being carried out on the north margin of the Amazonas Basin, by the Research Group "Geologia Sedimentar da Amazônia - GSA" from Universidade Federal do Amazonas (UFAM), aiming to identify and map the possible presence of post-cretaceous deposits, specially Miocene, in the region, evaluating the hypothesis of a greater coverage of these strata in the area, which would indicate a subsidence phase of the basin on the Miocene. Ten (10) samples were collected containing some organic content for palynological analysis, and five (5) resulted fertile (see Appendix I), which allowed the age and depositional environment definition of their supporting layers.

The palynoflora retrieved from carbonaceous pelitic levels of Novo Remanso Formation is moderately rich and diverse, and it is in reasonable conditions of preservation. It is quite similar to that association identified by Dino et al. (2012) for this same formation in two localities in Manacapuru, west of Manaus, and is composed of angiosperms and gymnosperms related pollen grains, pteridophytes spores, algae, fungi and scolecodonts. Seven hundred and eight palynomorphs were counted, comprising 43 genera and 58 species.

Figure 6 summarizes the palynological data and shows that the spore-pollen assemblages are dominated by pollen grains related to angiosperms ( 23 genera, 28 species and 406 forms counted), comprising $58 \%$ of the palynomorphs identified, with and abundant presence of tricolpates and tricolporates forms; Retitricolpites, Bombacacidites and Perisyncolporites are the most common genera. The second most represented group is the

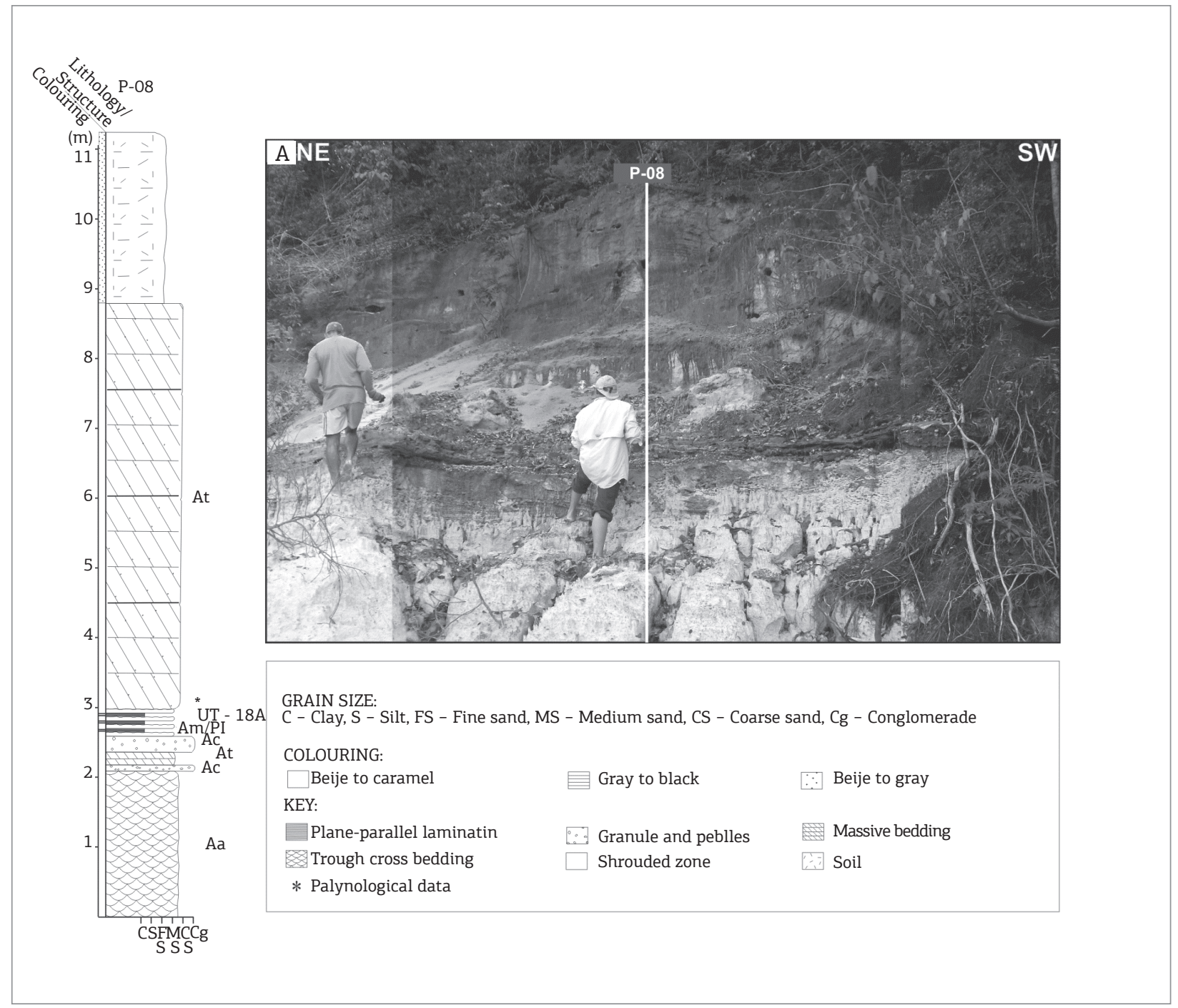

Figure 4. Outcrop panoramic and columnar sections on the Uatumã River right bank (P-08 Locality) (detail A). Aa, Ac, At, Am and Pl correspond to the sedimentary facies. 
pteridophytes spores (12 genera, 18 species and 239 counted grains) that make up $33 \%$ of the association; Polypodiisporites, Deltoidospora and Psilatriletes are quite frequent. The other representatives are minor components of the palynoflora, with percentages not exceeding 3\%, while on the group of gymnosperms only 2 genera were identified (Inaperturopollenties and Ephedripites); algae (including here the genus Chomotriletes $=$ Concentricystes) had 3 genera and 5 species. Among the fungi, only 1 genus was identified and 11 forms counted.

The palynoflora is non-marine, as evidenced by the lack of marine microphytoplankton (dinoflagellates cysts, microforaminiferal linings and acritarchs) and by the abundance of pollen grains and spores, freshwater algae and woody

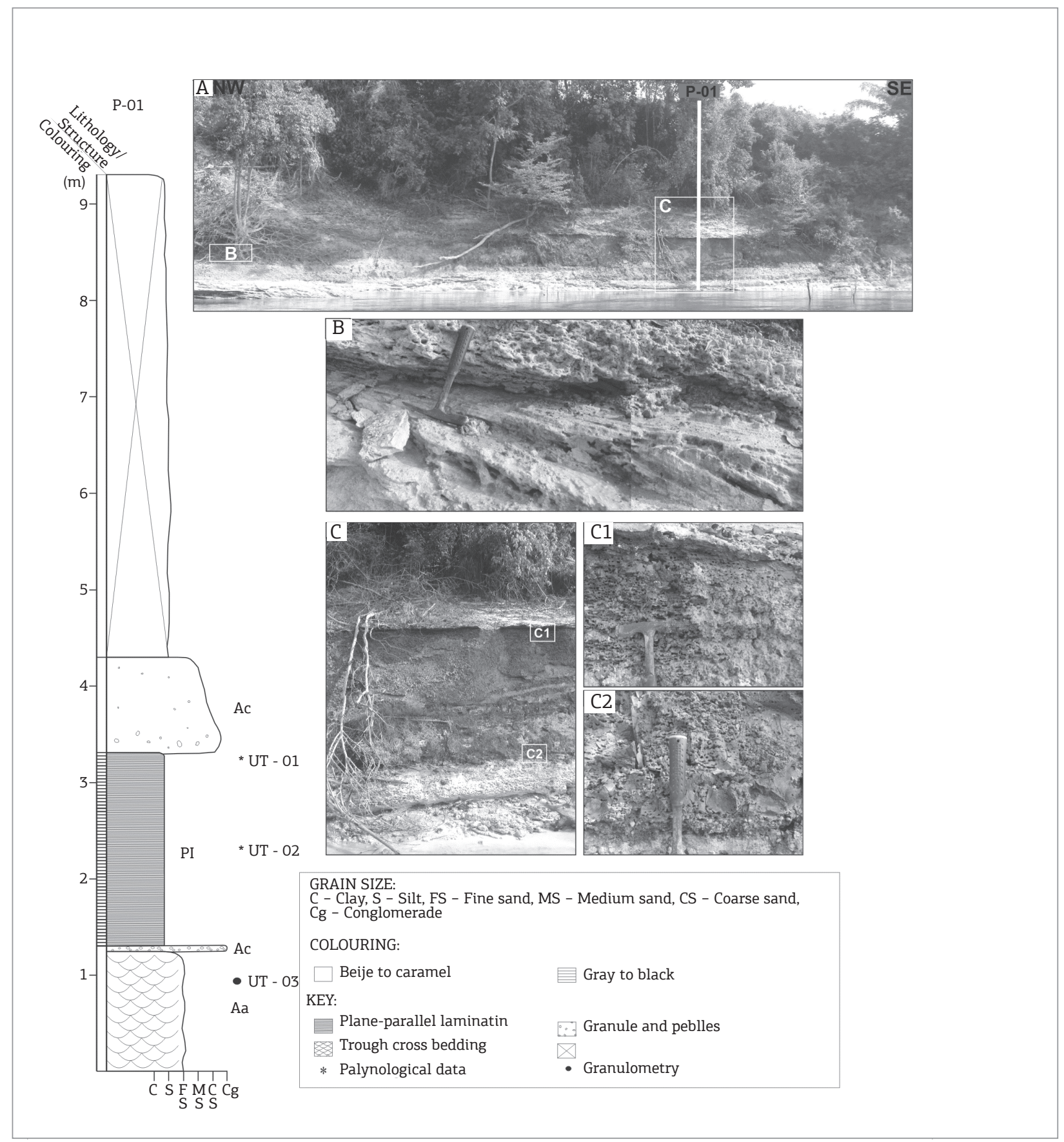

Figure 5. Outcrop panoramic and columnar sections of the Uatumã River left margin (P-01 locality) (detail A). The detail B displays sandstone layer with trough cross-bedding. The detail C shows the pelite layer with the collected samples, stressing their upper limits (detail C1) and bottom (detail C2). Aa, Ac and Pl correspond to the sedimentary facies. 
organic residue of continental origin. Coastal or transitional environmental indicative forms such as pollen grains typical of mangrove plants (e.g. Rhyzophora, Avicennia) were not identified either.

The most important palynoflora constituents indicate that the dominant paleovegetation at the Novo Remanso Formation deposition time was composed by Palm forests (Mauritiidites), lowland forests (Bombacacidites, Perisyncolporites) and aquatic components (Deltoidospora, Botryococcus, Chomotriletes) in hot and humid climatic conditions. Particularly important in the paleoenvironmental definition is the frequent presence of the following species: Bombacacidites spp., representing tropical forests developing trees (Fuchs 1964) and common along rivers and streams, being well adapted to poor, sandy and well drained soils (Hoorn 1994a); Jandufouria seamrogiformis, indicative of plants well adapted to inner alluvial plain environments (Barbeito et al. 1985); Magnastriatites grandiosus, indicating shallow water environments, ravines of rivers and wetlands in floodplains; Mauritiidites franciscoi, dominates in freshwater swampy areas and floodplains (Barbeito et al. 1985); and the occurrence in relatively high percentages of spores of the genera Polypodiisporites, Deltoidospora and Psilatriletes is common in tropical to subtropical regions.
This data set corroborates the prior information provided by different researchers (Dueñas 1980, Monsh 1998, Jaramillo \& Dilcher 2000, Pardo-Trujillo et al. 2003, Helenes \& Cabrera 2003, Silva 2004, Jaramillo et al. 2007, Latrubesse et al. 2007, Dino et al. 2012) who claim that in the Amazonia region and in all of northern South America a generally hot and humid climate prevailed in the Middle-Late Miocene. What is more, palynological data presented herein corroborate the interpretation of the sedimentological data.

From a biostratigraphic standpoint, the most conspicuous species identified include Bombacacidites baumfalki, Crototricolpites annemariae, Psilastephanoporites tesseroporus, Syncolporites poricostatus, Deltoidospora adriennis, Jandufouria seamrogiformis, Malvacearumpollis estelae, Mauritidiites franciscoi, Perisyncolporites pokornyi, Polypodiaceiosporites potoniei, Striatopollis catatumbus, Retitricolpites simplex, Perforotricolpites digitatus and Polypodiisporites usmensis. Their co-occurrences allow us to set the containing sediments into the Grimsdalea magnaclavata palynozone (sensu Regali et al. 1974a, 1974b), and Grimsdalea magnaclavatal Crassoretitriletes vanraadshooveni palynozones of Jaramillo et al. (2011) despite the absence of the species bearing its name, and considered Middle Miocene age. It should be noted that most of these species are characterized primarily

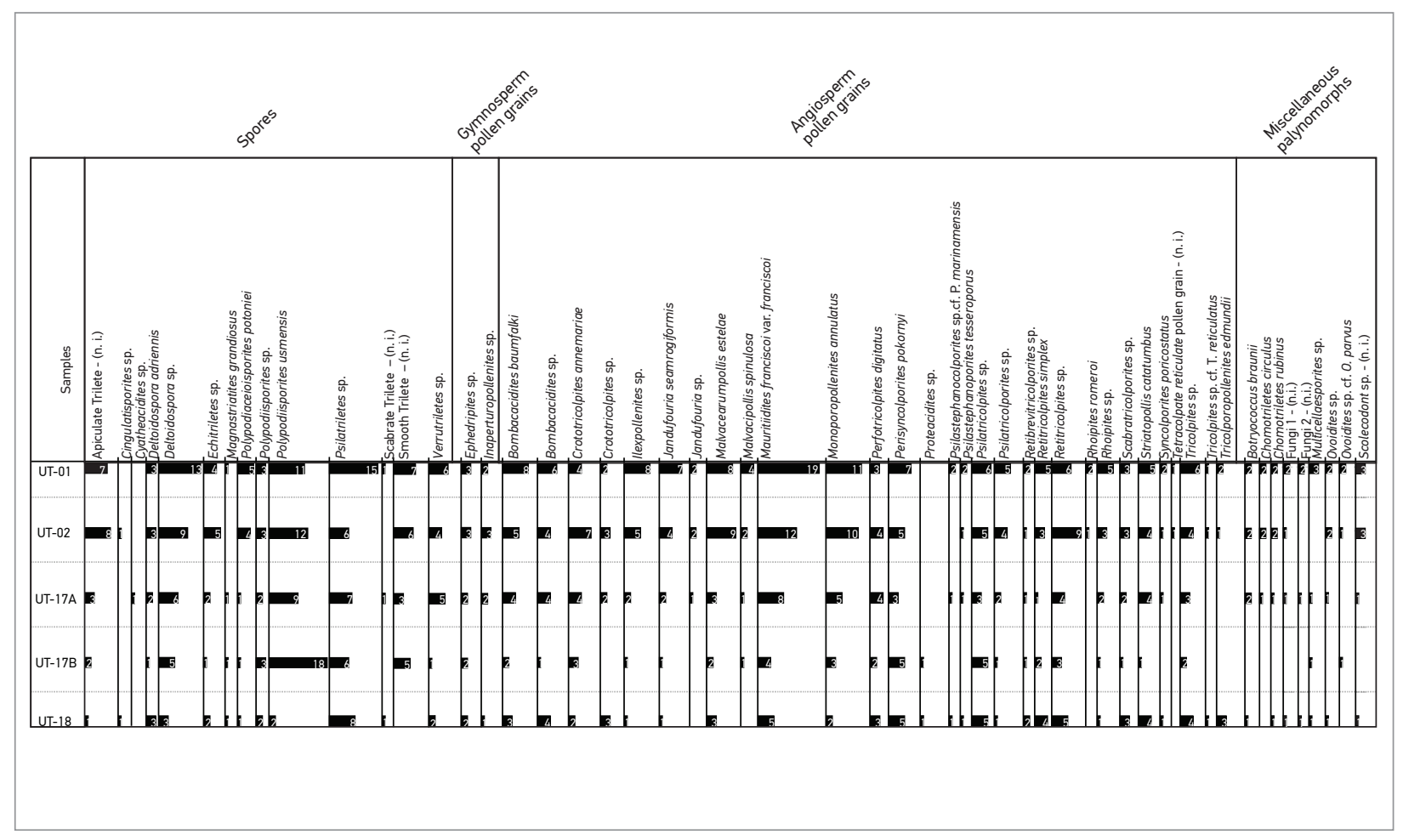

Figure 6. Summary diagram for palynological data. Number of counted specimens by outcrop sample of the Novo Remanso Formation. 
by long-ranging distribution taxa derived from the regional north South American flora, and have no temporal distribution restricted to the Miocene, although they are consistently represented in all palynological assemblages retrieved from the Neogene strata of Amazonia. Particularly for age constraints, the most useful species in this assemblage are Bombacacidites baumfalki, Crototricolpites annemariae, and Psilastephanoporites tesseroporus, which delimit this assemblage age to the Middle Miocene. As can be seen in Fig. 7, this age is confirmed by data from the more recent palynological zonation established by Jaramillo et al. (2011) for the strata of northern South America, on the basis of palynomorphs and independently calibrated with data from foraminifera, isotopes and magnetoestratigraphy. Specifically the first occurrence of Psilastephanoporites tesseroporus (FAD) and the last (LAD) occurrences of Bombacacidites baumfalki and Crototricolpites annemariae, defined by Jaramillo et al. (2011), constrain the identified assemblage age of the Novo Remanso formation to the Middle Miocene (14.00 to $11.57 \mathrm{Ma}$ ).

\section{DISCUSSION}

Regarding the association and interpretation of the sedimentary facies, two associations were identified: channel fill deposits (Ac, At, Aa and Am facies) and external to the channel (Pl and Am facies), characteristics of a meandering fluvial paleoenvironment.

The massive aspect of Ac and the poor selection of clasts suggest a relatively rapid sedimentation with moderated to high energy flux carrying sediments as bedload, consistent with the deposition on the inner parts of river channels (lag) as suggested by Miall (1992) and Collinson (1996).

The At and Aa facies were developed through tractive processes under the action of predominantly unidirectional currents, which induced the migration of sinuous and straight ridges bars (Collinson 1996; Miall 1996), respectively, deposited in a lower flow river channel. Moreover, the poor to moderate selection of sandstones and the predominance of unimodal orientation of the cross-strata direction suggest these kinds of bedforms.

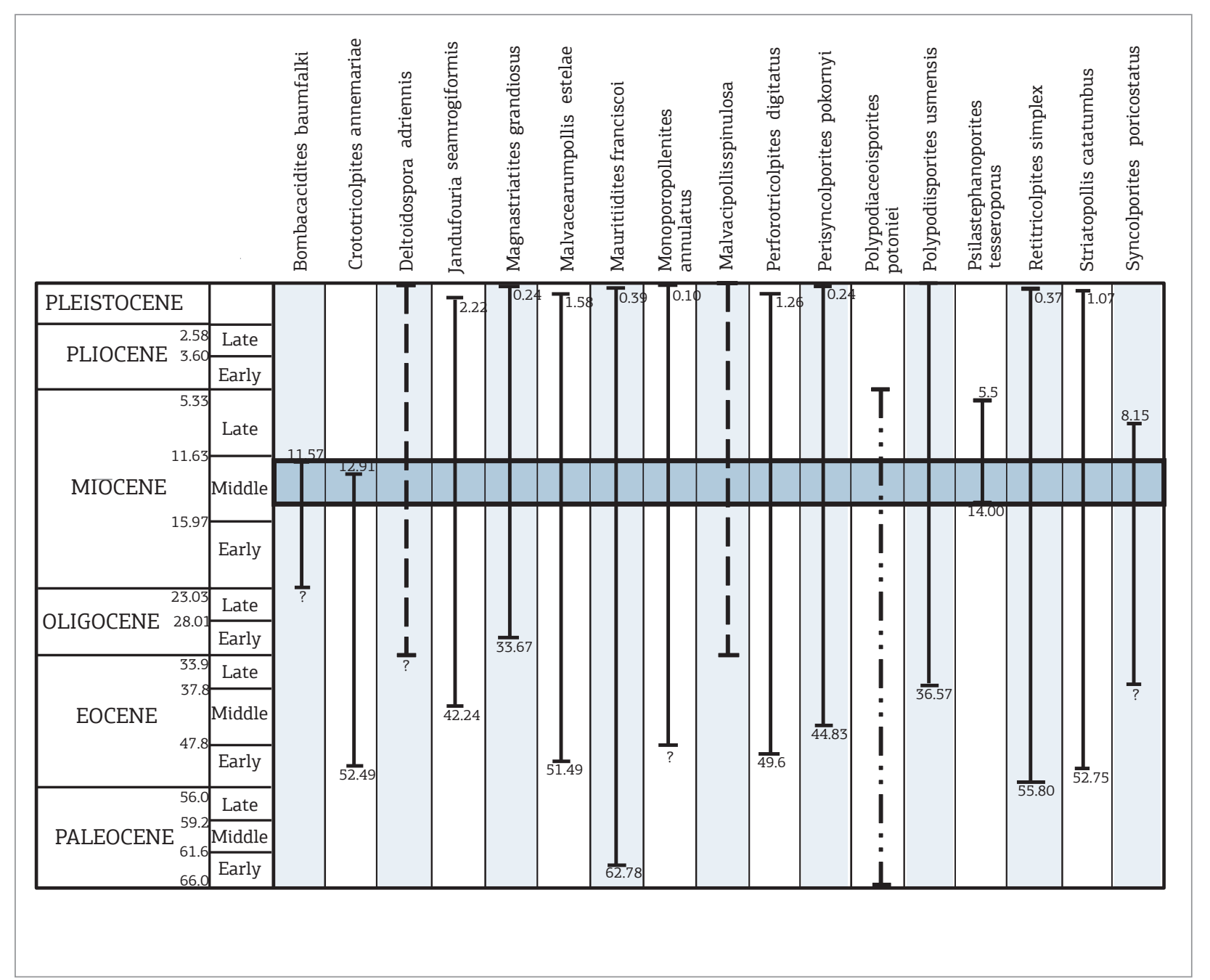

Figure 7. Compilation of stratigraphic ranges of selected species recorded from the Novo Remanso Formation. 
The Am facies does not present any evidence of bioturbation, which is suggestive of a rapid deposition of thick sandy bars on the river channel, where there was no sufficient time to the development of primary sedimentary structures.

The Pl facies is developed by thin material deposition from the suspension process or by sedimentation in extremely weak currents in low-energy environment, such as floodplain. Sometimes, thin interbedded sandstones of Am facies in $\mathrm{Pl}$ facies can be associated with crevasse splay deposits occurring adjacent to the main channel. The frequency of $\mathrm{Pl}$ facies overlying the thicker channel deposits (Ac, Aa and At facies) can indicate finning-upward cycles, characteristic of meandering fluvial system.

The palynological results presented allow us to extend the occurrence of Miocene deposits in the central Amazonas basin, previously restricted to two locations in Manacupuru, and reaffirm they are correlated with the Solimóes Formation, in the Solimóes Basin, and the Barreiras-Pirabas Formations in eastern Amazonia, and with chrono-correlated strata from northern South America and the Caribbean basins zones. The most important palynomorphs recovered from the Novo Remanso Formation palynoflora are presented in the Figs. 8 to 11 .

Regarding the Novo Remanso Formation age, it should be noted that Guimarães et al. (2015) indicated that the age sediments they analyzed can be in the range of Middle Miocene to Pliocene. However, their palynomorph findings do not provide a better biostratigraphy resolution and besides the authors did not take into consideration that: (a) if the Nova Remanso Formation reaches the Pliocene age, it would be expected that the pollen association contained forms originating from the Andes, which does not occur. Figueiredo et al. (2009) indicated that from the top of the Miocene era, the Amazon River had already reached the Atlantic, and, therefore, as a consequence, sediments were being brought from the Andes throughout the Amazon region; (b) data from Horbe (2014) confirm the dating indicated by Dino et al. (2012), by ascribing to the overlying lateritic crusts of the Novo Remanso Formation a maximum age of $10 \mathrm{Ma}$, meaning that sediments below this level cannot be younger than $10 \mathrm{Ma}$.; (c) they do not discuss the absence of guide-forms proving newer than middle Miocene ages such as: Fenestrites spinosus, Cyatheacidites annulatus, Echitricolportes moneillyi, etc., which are common in the region's valid palynozones (e.g. Lorente 1986, Hoorn 1993, Jaramillo et al. 2011). These species are constant not only in valid biostratigraphic frameworks for Northern South America but are also part of the Brazilian marginal basin palynostratigraphic framework and rely on large independent controls (foraminifera and nannofossil biozones).

\section{CONCLUSIONS}

The main objective of this research was to set, by means of sedimentological, palynological and stratigraphic studies, the occurrence of the Novo Remanso Formation Miocene deposits in the middle to lower sections of Uatumã River (Itapiranga and São Sebastião do Uatumã municipalities boundaries), east of Manaus.

The studied deposits (Novo Remanso Formation) consist mainly of sandstones with conglomerates and subordinate pelites which constitute the bedload channel, fluvial bars, floodplain and crevasse splay facies, representing a meandering fluvial paleoenvironment. The identified facies, as well as palynological assemblage recovered here, are similar to those defined by Dino et al. (2012) for this same formation in Manacapuru region, west of Manaus. This new discovery has allowed extending the area of occurrence of this unit for about $300 \mathrm{~km}$, reinforcing the hypothesis of subsidence of the basin during this period, unlike the uplift proposed by Rossetti et al. (2005).

Faced with new palynostratigraphical data, part of the sedimentary cover of the central portion of the Amazonas Basin, exclusively attributed to Cretaceous unit (Alter do Chão Formation) in regional geological maps (CPRM 2006, 2008) and the sedimentary record of the tectonic depressions (grabens) of the northern edge of the basin (Nogueira et al. 1997) should be reviewed. Despite the lack of palynological data, the sedimentary record of the grabens should be of Miocene age, related to the subsidence event that affected the basin during this period, and allowed the progress of Miocene sedimentation on the north border.

The presence of the Bombacacidites baumfalki, Crototricolpites annemariae and Psilastephanoporites tesseroporus species ensure that these deposits, in temporal terms, are limited to the Middle Miocene age (14.00 to 11.57 Ma).

The palynological association indicates that the depositional environment was non-marine, as evidenced by the absence of marine microphytoplankton (dinoflagellates cysts, microforaminiferal linings and acritarchs) and by the high abundance of pollen grains and spores, freshwater algae and woody organic residue of continental origin. Likewise, coastal or transitional environments indicative forms were not identified, such as pollen grains related to typical mangrove plants (e.g. Rhizophora, Avicennia). 

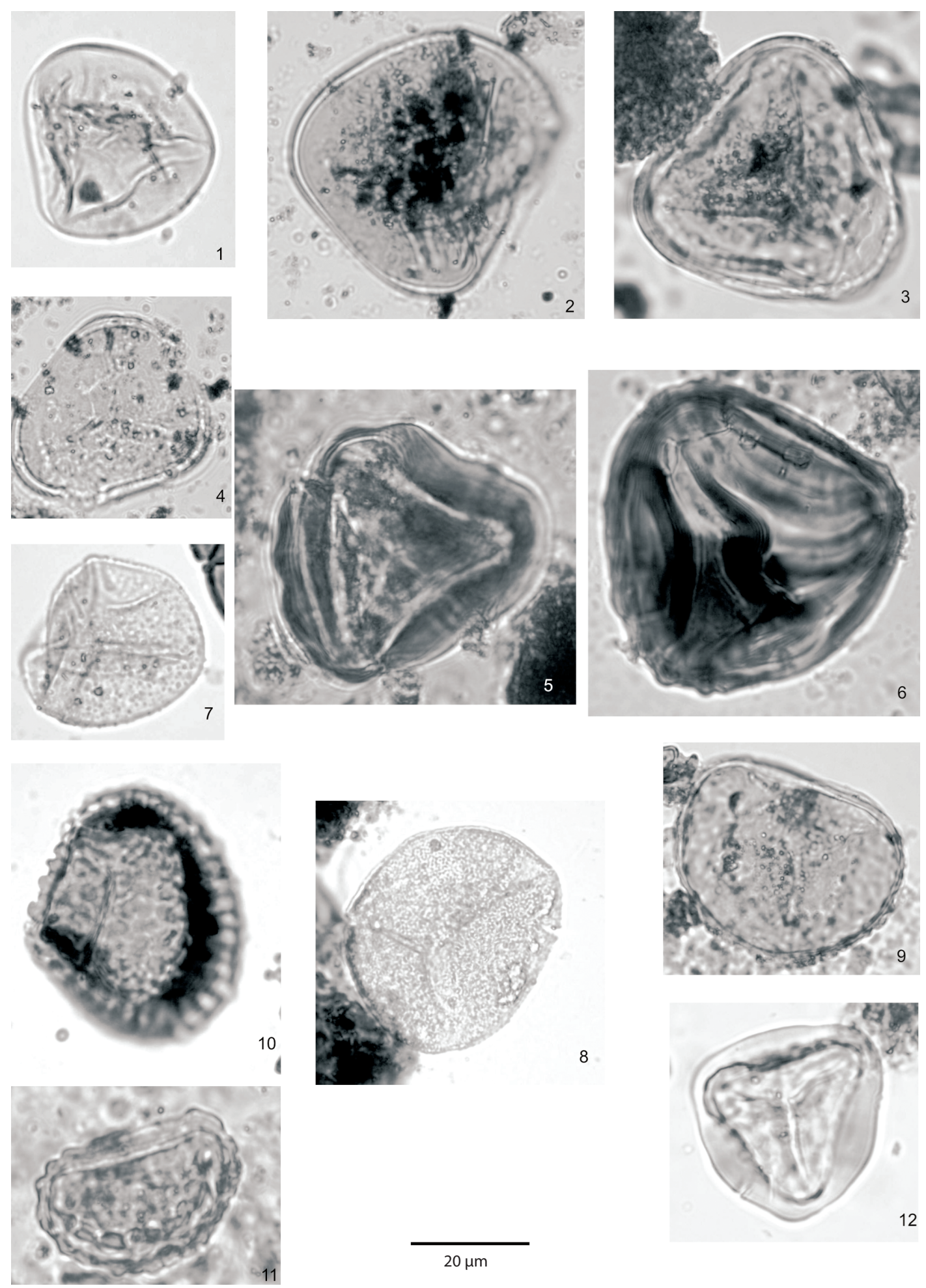

8

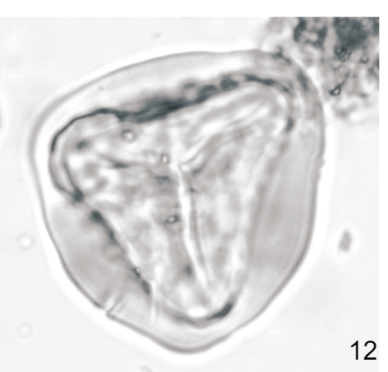

$20 \mu \mathrm{m}$

Figure 8. 1. Psilatriletes sp. (slide UT-01. Coord. E.F. U52-1); 2. Deltoidospora sp. (slide UT-17A. Coord. E.F. Q55-1); 3. Cytheacidites sp. (slide UT-17A. Coord. E.F. 043-1); 4. Deltoidospora adriennis (slide UT-17A. Coord. E.F. J56-2); 5. Cingulatisporites sp. (slide UT-02. Coord. E.F. Z45-3); 6. Magnastriatites grandiosus (slide UT-17B. Coord. E.F. B51-1); 7. Echitriletes sp. (slide UT-01. Coord. E.F. R56); 8. Scabrate Trilete - not identified (slide UT-01. Coord. E.F. D38-1); 9. Polypodiisporites sp. (slide UT-17B. Coord. E.F. R45); 10. Verrutriletes sp. (slide UT-01. Coord. E.F. F45-1); 11. Polypodiisporites usmensis (slide UT-02. Coord. E.F. E54-4); 12. Polypodiaceioisporites potoniei (slide UT-01. Coord. E.F. P45-2). 

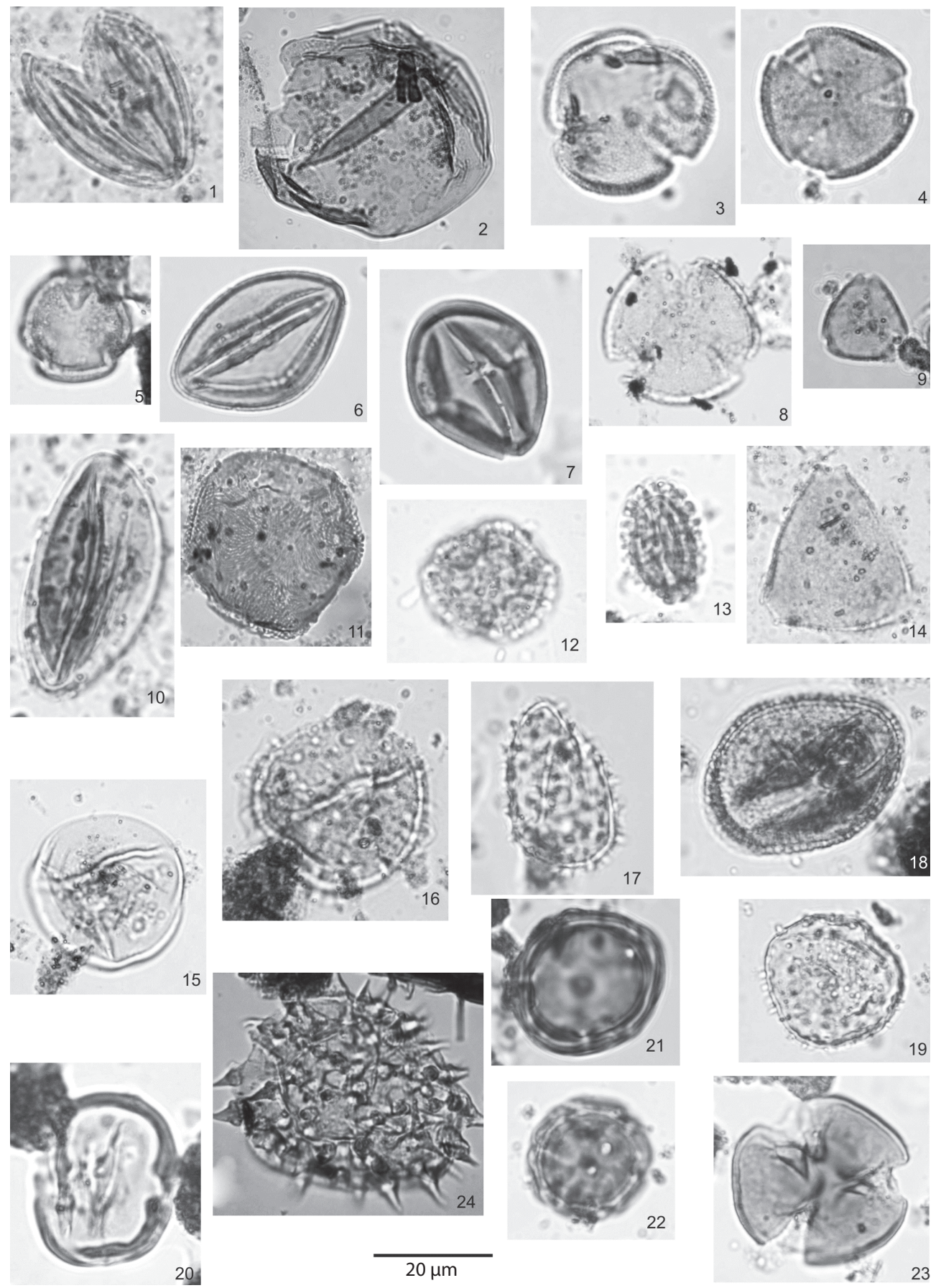

Figure 9. 1. Ephedripites sp. (slide UT-18. Coord. E.F. J44); 2. Inaperturopollenites sp. (slide UT-17A. Coord. E.F. D42-1); 3. Tricolpites sp. cf. T. reticulatus (slide UT-01. Coord. E.F. P47-2); 4. Scabratricolporites sp. (slide UT-01. Coord. E.F. V54-4); 5. Retibrevitricolporites sp. (slide UT-01. Coord. E.F. W42-4); 6, 7. Tricolporopollenites edmundii (6- slide UT-18. Coord. E.F. 056-4; 7- slide UT-01. Coord. E.F. Q50); 8. Tricolpites sp. (slide UT-01. Coord. E.F. 043-1); 9. Syncolporites poricostatus (slide UT-01. Coord. E.F. S41-1); 10. Psilatricolpites sp. (slide UT-17A. Coord. E.F. N56-1); 11. Striatopollis catatumbus (slide UT-01. Coord. E.F. H61-2); 12, 13. Ilexpollenites sp. (12- slide UT-01. Coord. E.F. D46; 13 - slide UT-01. Coord. E.F. Y38-3); 14. Proteacidites sp. (slide UT-18. Coord. E.F. 036-4); 15. Monoporopollenites annulatus (slide UT-01. Coord. E.F. 063-1); 16, 17. Mauritiidites franciscoi var. franciscoi (16- slide UT-01. Coord. E.F. R64; 17- slide UT-17A. Coord. E.F. B41-3); 18. Rhoipites sp. (slide UT-02. Coord. E.F. J33-1); 19. Malvacipollis spinulosa (slide UT-01. Coord. E.F. Q32-4); 20. Psilastephanocolporites cf. P. marinamensis (slide UT-01. Coord. E.F. H61-4); 21, 22. Perisyncolporites pokornyi (21- slide UT-17B. Coord. E.F. L44; 22- slide UT-17A. Coord. E.F. M43-3); 23. Psilatricolporites sp. (slide UT-02. Coord. E.F. Z39-2); 24. Malvacearumpollis estelae (slide UT-01. Coord. E.F. Q25-1). 

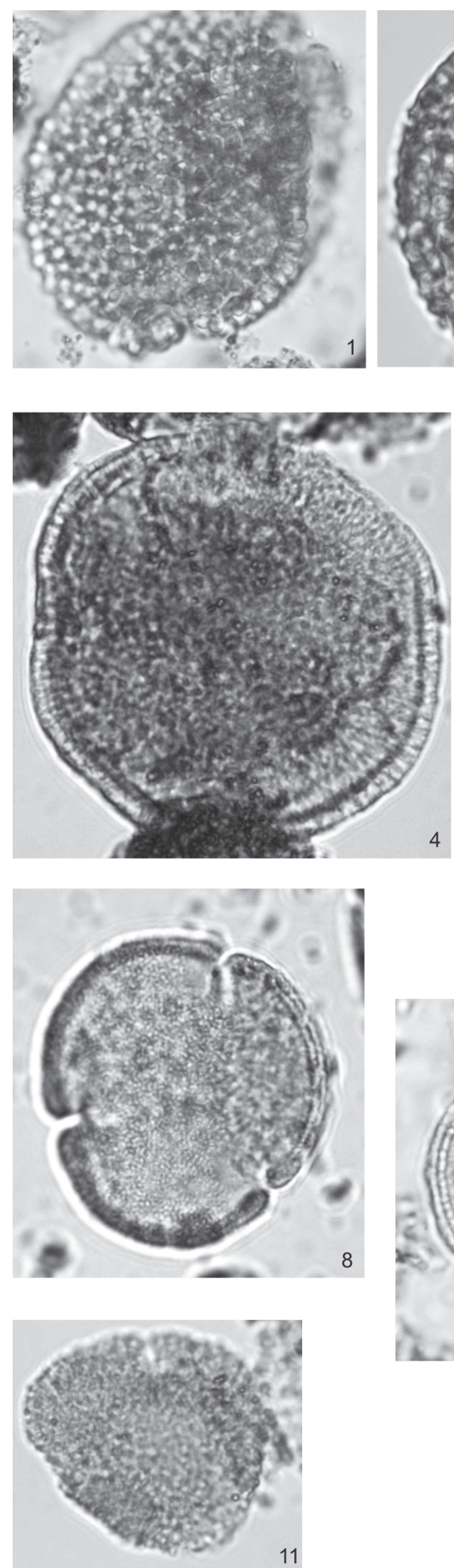
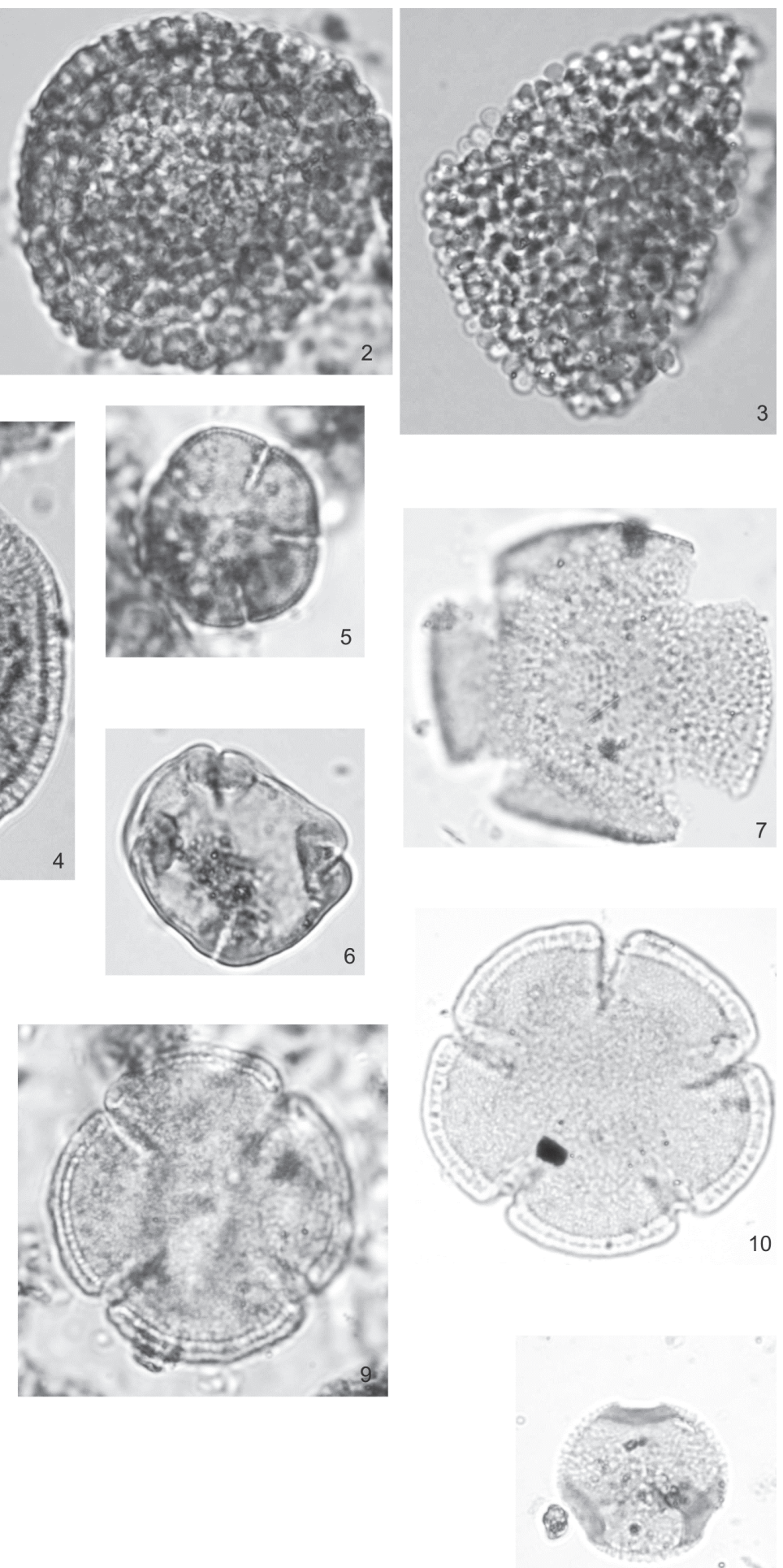

$20 \mu \mathrm{m}$

Figure 10. 1, 2. Crototricolpites annemariae (1-slide UT-02. Coord. E.F. W27-1; 2-slide UT-17B. Coord. E.F. U58-4); 3. Crototricolpites sp. (slide UT-01. Coord. E.F. 043-2); 4. Perfotricolpites digitatus (slide UT-01. Coord. E.F. U55-3). 5. Jandufouria sp. (slide UT-02. Coord. E.F. E28); 6. Psilastephanoporites tesseroporus (slide UT-01. Coord. E.F. T43); 7. Tetracolpate reticulate pollen grain - not identified (slide UT-02. Coord. E.F. J60-2); 8. Bombacacidites baumfalki (slide UT-01. Coord. E.F. L33-1); 9, 10. Jandufouria seamrogiformis (9- slide UT-02. Coord. E.F. O28-4; 10- slide UT-01. Coord. E.F. H58); 11. Bombacacidites sp. (slide UT-17B. Coord. E.F. S55-3); 12. Rhoipites romeroi (slide UT-01. Coord. E.F. C46-2). 

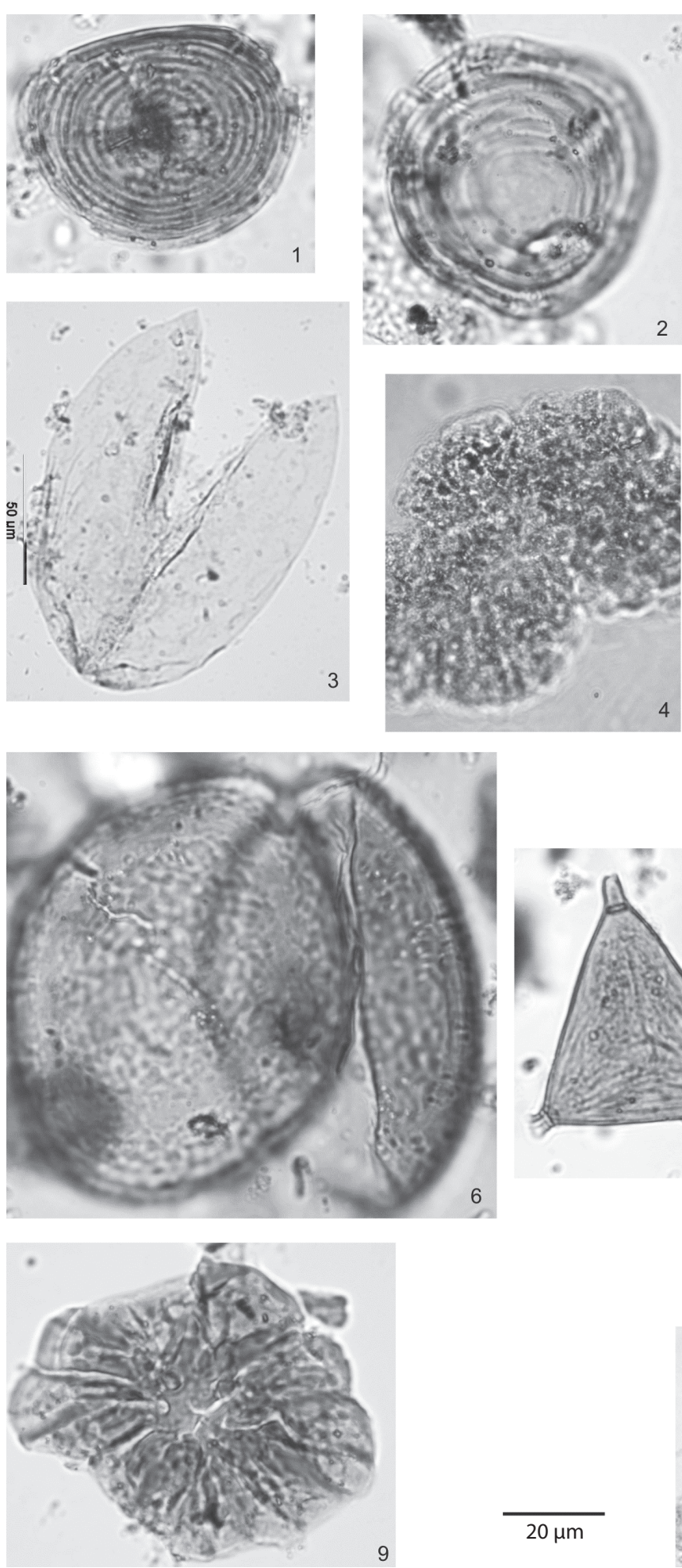

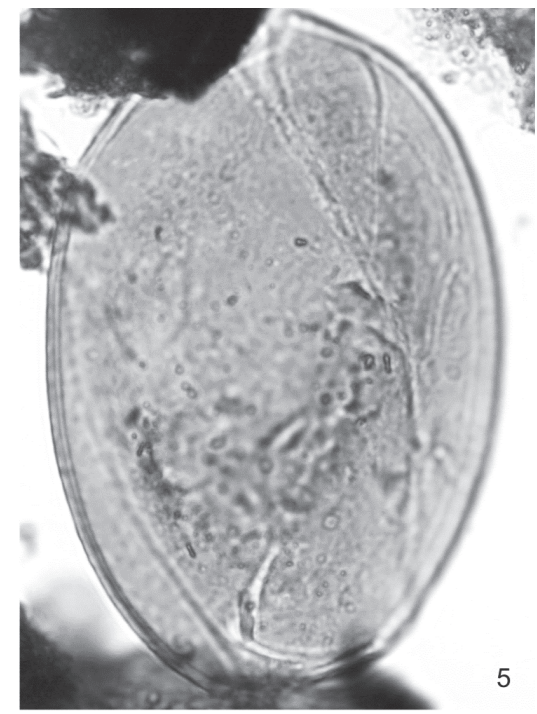

4
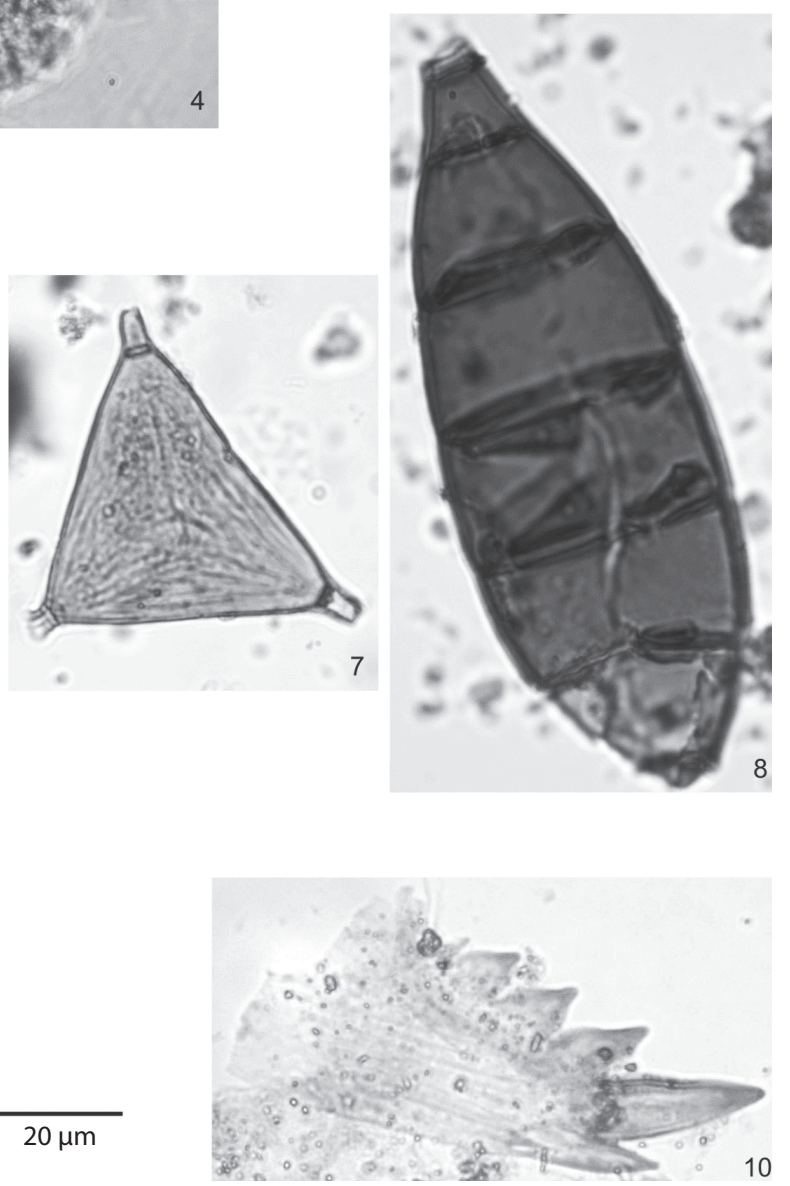

Figure 11. 1. Chomotriletes rubinus (slide UT-02. Coord. E.F. W28-2); 2. Chomotriletes circulus (slide UT-01. Coord. E.F. P43-3); 3. Ovoidites sp. cf. O. parvus (slide UT-17B. Coord. E.F. Y57); 4. Botryococcus braunii (slide UT-17A. Coord. E.F. L52-1); 5. Ovoidites parvus (slide UT-01. Coord. E.F. H46-2); 6. Ovoidites sp. (slide UT-02. Coord. E.F. S40); 7. Fungi 1 - not identified (slide UT-02. Coord. E.F. S39-3); 8. Multicellaesporites sp. (slide UT-17A. Coord. E.F. T44); 9. Fungi 2 - not identified (slide UT-17B. Coord. E.F. F40-2); 10. Scolecodont sp. - not identified (slide UT-01. Coord. E.F. F63-4). 
The dominant paleovegetation consist of palms forests (Mauritiidites), lowland forests (Bombacacidites, Perisyncolporites) and aquatic components (Deltoidospora, Botryococcus, Chomotriletes) which were developed under hot and humid climatic conditions. This paleovegetation developed over the floodplain of the Central Amazon Neogene river paleosystem.

\section{ACKNOWLEDGMENTS}

The authors thank the Conselho Nacional de Desenvolvimento Científico e Tecnológico (CNPq, $\left.\mathrm{n}^{\circ} 470888 / 2011-3\right)$ for the financial support needed to develop and complete this study.

\section{REFERENCES}

Andrade L.S. \& Soares E.A.A. 2009. Estratigrafia de subsuperfície da seqüência sedimentar cretácea e neógena na cidade de Manaus. In: XI Simpósio de Geologia da Amazônia, Anais, SBG-NO, Manaus.

Barbeito P.J., Pittelli R., Evans A.M. 1985. Estudio estratigráfico del Eoceno en el área de Mara-Maracaibo, Venezuela occidental, basado en interpretaciones paleontológicas y palinológicas. In: VI Congresso Geológico Venezolano, Venezuela, p. 109-139.

Caputo M.V. 1984. Stratigraphy, tectonics, paleoclimatology and paleogeography of northern basins of Brazil. PhD Thesis, University of California, Santa Barbara, 583 p.

Caputo M.V. 2009. Discussão sobre a Formação Alter do Chão e o Alto de Monte Alegre. In: XI Simpósio de Geologia da Amazônia, Anais, SBG-NO, Manaus.

Caputo M.V. 2011. Discussão sobre a Formação Alter do Chão e o Alto de Monte Alegre. In: Nascimento R.S.C., Horbe A.M.C., Almeida C.M (coord.). Contribuições à Geologia da Amazônia Manaus, 7º SBG-NO, 7-23 p

Collinson J.D. 1996. Alluvial Sediments. In: Reading H.G. (ed.) Sedimentary Environments and Facies, 3.ed. Oxford, Blackwell, p. 37-82.

Costa A.R.M. 2002. Tectônica cenozóica e movimentação salífera na Bacia do Amazonas e suas relações coma geodinâmica das placas da América do Sul, Caribe, Cocos e Nazca. MS Dissertation, Centro de Geociências, Universidade Federal do Pará, Belém, 237 p.

Costa M.L. 1991. Aspectos geológicos dos lateritos da Amazônia. Revista Brasileira de Geociências, 21(2):146-160.

CPRM. 2006. Geologia e Recursos Minerais do Estado do Amazonas. MME/CPRM/CIAMA, Programa de Geologia do Brasil (mapas geológicos estaduais, escala 1:1.000.000), Manaus, Texto Explicativo, 144p, CR-ROM

CPRM. 2008. Informe de Recursos Minerais - Programa Geologia do Brasil: Série Rochas e Minerais Industriais $N^{\circ} 3$ - Projeto de materiais de construção no domínio Médio Amazonas (Mapa Geológicos e de Recursos Minerais, escala 1:1.250.000), Manaus, $168 \mathrm{p}, \mathrm{CR}-\mathrm{ROM}$.

Cunha P.R.C., Gonzaga F.G., Coutinho L.F.C., Feijó F.J. 1994. Bacia do Amazonas. Boletim de Geociências da Petrobras, 8(1):47-55.

Cunha P.R.C., Melo J.H.G., Silva O.B. 2007. Bacia do Amazonas. Boletim de Geociências da Petrobras, 15(2):227-251.

Daemon R.F. \& Contreiras C.J.A. 1971. Zoneamento palinológico da Bacia do Amazonas. In: Congresso Brasileiro de Geologia, Anais, São Paulo, SBG, p. 79-88.

Da Silva-Caminha S.A.F., Jaramillo C., Absy M.L. 2010. Neogene palynology of the Solimões Basin, Brazilian Amazonia. Palaeontographica Abteilung B. Palaeophytology e Palaeobotany, 284(1-3):13-79.
Dino R., Soares E.A.A., Riccomini C., Antonioli L., Nogueira A.C.R. 2006. Caracterização palinoestratigráfica de depósitos miocênicos da Bacia do Amazonas, região de Manacapuru, AM. In: VII Simpósio do Cretáceo do Brasil, I Simpósio Do Terciário Do Brasil, Serra Negra, IGCE/UNESP, p. 43.

Dino R., Soares E.A., Antonioli L., Riccomini C., Nogueira A.C. 2012 Palynostratigraphy and sedimentary facies of miocene fluvial deposits of the Amazonas Basin, Brazil. Journal of South American Earth Sciences, 34:61-80.

Dueñas H. 1980. Palynology of Oligocene/Miocene strata of borehole Q-E-22, Planeta Rica, northern Colômbia. Review of Palaeobotany and Palynology, 10:318-28.

Fuchs H.P. 1964. Preliminary notes on the palynomorphology of some representatives of the family of Bombacaceae. Internal Shell report, Rijswijk, 19 p.

Gonçalves Júnior E.S. 2013. Terraços fluviais quaternários das regiões do Careiro-da-Várzea, Manaquiri, Careiro-Castanho e Autazes, Amazônia Central. MS Dissertation, Instituto de Geociências, Universidade Federal do Amazonas, Manaus, 127p.

Germeraad J.H., Hopping C.A, Muller J. 1968. Palynology of Tertiary sediments from tropical areas. Review of Palaeobotany and Palynology, 6:189-348

Guimarães J.T.F., Nogueira A.C.R., Silva Júnior J.B.C., Soares J.L., Alves R. \& Kern A.K. 2015. Palynology of the middle Miocene-Pliocene Novo Remanso Formation, central Amazonia, Brazil. Ameghiniana, 52(1):107-134

Helenes J. \& Cabrera D. 2003. Oligocene/Miocene palynomorph assemblages from eastern Venezuela. Palynology, 27:5-25.

Horbe A.M.C., Nogueira A.C.R., Horbe M.A., Costa M.L., Suguio K. 2001. A laterização na gênese das superfícies de aplainamento da região de Presidente Figueiredo, nordeste do Amazonas. In: Reis N. J. \& Monteiro M.A.S. (coord.). Contribuições à Geologia da Amazônia, $2^{\circ}$, SBG-NO, p. 145-176.

Horbe M.A.C., Horbe M.A., Suguio K. 2003. Origem dos depósitos de areias brancas no nordeste do Amazonas. Revista Brasileira de Geociências, 33(1):41-50.

Horbe M.A.C., Horbe M.A., Suguio K. 2004. Tropicals spodosols in Northeastern Amazon State, Brazil. Geoderma, 119:55-68.

Horbe M.A.C. 2014. Idades paleomagnéticas de crostas lateríticas da Amazônia. Boletim do Museu Paraense Emílio Goeldi. Série Ciências Naturais (Cessou em 2005. Cont. ISSN 1981-8114 Boletim do Museu Paraense Emílio Goeldi. Ciênci, 9:93-104.

Hoorn C. 1993. Marine incursions and the influence of Andean tectonics on the depositional history of north-western Amazonia: results of a palynological study. Palaeogeography, Palaeoclimatology, Palaeoecology, 105:267-309. 
Hoorn C. 1994a. Miocene palynostratigraphy and paleoenvironments of northwestern Amazonia: evidence for marine incursions and the influence of Andean tectonics. Unpubl. PhD thesis, University of Amsterdam, Holand, 156 pp.

Hoorn C. 1994b. Fluvial palaeoenvironments in the intracratonic Amazonian Basin (Early Miocene/Early-Middle Miocene, Colombia). Palaeogeography, Palaeoclimatology, Palaeoecology, 109:1-54.

Hoorn C. 1994c. An environmental reconstruction of the palaeoAmazon River system (Middle/Late Miocene, NW Amazonia). Palaeogeography, Palaeoclimatology, Palaeoecology, 112:187-238.

Jaramillo C.A., Bayona G., Pardo-Trujillo A., Rueda M., Torres V. 2007. The Palynology of the Cerrejón Formation (Upper Paleocene) of Northern Colombia. Palynology, 31:153-189.

Jaramillo C.A., Rueda M., Torres V. 2011. A palynological zonation for the Cenozoic of the Llanos and Llanos Foothills of Colombia. Palynology, 35(1):46-84.

Jaramillo C.A. \& Dilcher D.L. 2000. Microfloral diversity patterns of the late Paleocene-Eocene interval in Colombia, northern South America. Geology, 28:815-818.

Jaramillo C.A. \& Dilcher D.L. 2001. Middle Paleogene palynology of central Colombia, South America: a study of pollen and spores from tropical latitudes. Palaeontographica Abt. B, 258:87-213.

Kotschoubey B. \& Truckenbrodt W. 1981. Evolução poligenética das bauxitas do distrito de Paragominas-Açailândia, Estados do Pará e Maranhão. Revista Brasileira de Geociências, 11(3):193-202.

Latrubesse E.M., Silva S.A.F., Cozzuol M., Absy M.L. 2007. Late Miocene continental sedimentation in southwestern Amazônia and its regional significance: biotic and geological evidence. Journal of South American Earth Sciences, 23:61-80.

Leite F.P.R., Oliveira M.E.B., Arai M., Truckenbrodt W. 1997. Palinoestratigrafia da Formação Pirabas e Grupo Barreiras, Mioceno do nordeste do Estado do Pará, Brasil. Revista da Universidade de Guarulhos, série Geociências, 2:141-147.

Leite F.P.R. 2007. Palinologia da Formação Solimões, Neógeno da Bacia do Solimões, estado do Amazonas: Implicações paleoambientais e bioestratigráficas. PhD thesis, Universidade de Brasília, Brasília, $138 \mathrm{p}$.

Lorente, M.A. 1986. Palynology and palynofacies of the upper Tertiary in Venezuela. PhD thesis, University of Amsterdam, J. Cremer, Berlin-Stuttgart, 225 p.

Leidelmeyer P. 1966. The Paleocene and lower Eocene pollen flora of Guyana. Leidse Geol. Meded., 38:49-70.

Miall A.D. 1985. Architectural-element analysis: A new method of facies analysis applied to fluvial deposits. Earth-Science Reviews, 22(4):261-308

Miall A.D. 1992. Alluvial deposits In: Walker R.G \& James N.P. (eds) Fácies models: response to sea levelchange. St. John's, Geological Association of Canada, 119-142 p.

Miall A.D. 1996. The Geology of Fluvial Deposits: Sedimentary Facies, Basin Analysis, and Petroleum Geology. New York, Springer-Verlag, 582 p.

Mendes J.C. 1957. Notas sobre a bacia sedimentar Amazônica. Boletim Paulista de Geografia, 26:3-35.

Muller J., Di Giacomo E., Van Erve A.W. 1987. A palynologic zonation for the Cretaceous, Tertiary, and Quaternary of Northern South America. AASP Contribibution Series, 19:7-76.
Nogueira A.C.R., Souza V., Soares E.A.A. 1997. Contribuição a tectônica cenozoica da região de Presidente Figueiredo, Norte de Manaus. In: VI Simpósio Nacional de Estudos Tectônicos, Pirenópolis (GO). p. 153-155.

Monsh K.A. 1998. Miocene fish faunas from the Northwestern Amazonia basin (Colombia, Peru, Brazil) with evidence of marine incursions. Palaeogeography, Palaeoclimatology, Palaeoecology, 143:31-50

Pardo-Trujillo A., Jaramillo C.A., Oboh-Ikuenobe F.E. 2003. Paleogene Palynostratigraphy of the Eastern Middle Magdalena Valley, Colombia. Palynology, 27:155-178.

Phipps D. \& Playford, G. 1984. Laboratory techniques for extraction of palynomorphs from sediments. Papers of Department of Geology, University of Queensland, 11:1-23.

Price L.I. 1960. Dentes de Theropoda num testemunho de sonda no estado do Amazonas. Anais da Academia Brasileira de Ciências, 32(1):79-84.

Regali M.S.P., Uesugui N., Santos A.S. 1974a. Palinologia dos sedimentos mesocenozoicos do Brasil.I. Boletim Técnico da Petrobras, 17(3):177-190.

Regali M.S.P., Uesugui N., Santos A.S. 1974b. Palinologia dos sedimentos mesocenozoicos do Brasil. II. BoletimTécnico da Petrobras, 17(4):263-301.

Rossetti D.F. 2001. Late Cenozoic sedimentary evolution in northeastern Pará, Brazil, within the context of sea level changes. Journal South American Earth Sciences, 14(1):77-89.

Rossetti D.F., Toledo P.M., Góes A.M. 2005. New geological framework for western Amazonia (Brazil) and implications for biogeography and evolution. Quaternary research, 63(1):78-89.

Rossetti D.F., Bezerra F.H.R., Dominguez J.M.L. 2013. Late OligoceneMiocene transgressions along the equatorial and eastern margins of Brazil. Earth Science Reviews, 123:87-112.

Rozo J.M.G. 2004. Evolução holocênica do Rio Amazonas entre a Ilha do Careiro e a foz do Rio Madeira. MS Dissertation, Instituto de Geociências, Universidade Federal do Amazonas, Manaus, 93 p.

Rozo J.M.G., Nogueira A.C.R., Horbe A.M.C., Carvalho A.S. 2005. Depósitos neógenos da Bacia do Amazonas. In: Horbe A.M.C. \& Souza V.S. (coord.) Contribuições à Geologia da Amazônia, Manaus, 4º, SBGNO, p. 201-207.

Silva S.A.F. 2004. Palinologia do Neógeno da Amazônia sul ocidental, Brasil. MS Dissertation, Instituto Nacional de Pesquisa da Amazônia, Manaus, $107 \mathrm{p}$.

Silva S.A.F. 2008. Palinologia do Neógeno da Bacia do Alto Solimões, Amazônia Ocidental, Brasil: Aspectos Sistemáticos, Bioestratigráficos e Paleoecológicos. PhD thesis, Instituto Nacional de Pesquisa da Amazônia, Manaus, 182 p.

Soares E.A.A. 2007. Depósitos pleistocenos da região de confluência dos rios Negro e Solimões, porção oeste da Bacia do Amazonas. PhD thesis, Instituto de Geociências, Universidade de São Paulo, São Paulo, $205 \mathrm{p}$.

Soares E.A.A., Tatumi S.H., Riccomini C. 2010. OSL age determinations of pleistocene fluvial deposits in central Amazonia. Academia Brasileira de Ciências, 82(3):14-9.

Travassos W.A.S. \& Barbosa Filho C.M. 1990. Tectonismo terciário na área do rio Tapajós, Bacia do Amazonas. Boletim de Geociências Petrobrás, 4(3):299-314. 
Van Der Hammen T. 1957a. Palynologic stratigraphy of the Sabana de Bogota (East Cordilera of Colombia). Boletín Geológico, Bogotá, 5:187-203.

Van Der Hammen T. 1957b. Climatic periodicity and evolution of South American Maestrichtian and Tertiary Floras: a study based on pollen analysis in Colombia. Boletín Geológico, Bogotá, 5:49-91.

Van Der Hammen T. \& Wijmstra T.A. 1964. A palynological study on the tertiary and Upper Cretaceous of British Guiana. Leidse Geol. Meded., 30:183-241.

Walker R.G. 1992. Facies, facies models and modern stratigraphic concepts. In: Walker R.G. \&

James N.P. (eds.) Facies Models - Response to sea Level Change. St. John's, Geological Association of Canada, p. 1-14.

Walker R.G. 2006. Facies Models Revisited. In: Posamentier H.W. \& Walker R.G. (eds.) Facies Models Revisited. Tulsa, SEPM Society for Sedimentary, p. 1-17.
Wijmstra T.A. 1971. The Palynology of the Guiana Coastal Basin. Drukkerij de Kempenaer, Oegstgeest, Utrecht, 66 p.

Wisevich M. 1991. Photomosaics of outcrops: useful photografic techniques. In: Mial A.D. \& Tyler N. The three-dimensional facies arquitecture of terrigenous clastic sediments and its implications for hydrocarbon discovery and recovery. Society for Sedimentary Geology/SEPM (Concepts in Sedimentology and Paleontology, 3), Tulsa, p. 22-24.

Wood G.D., Gabriel A.M., Lawson J.C., 1996. Palynological techniques e processing and microscopy. In: Jansonius, J. \& McGregor D.C. (Eds.), 1996. Palynology: Principles and Applications, 1. American of Stratigraphic Palynologists Foundation, Dallas, Texas, p. 29-50.

Arquivo digital disponível on-line no site www.sbgeo.org.br 
Appendix 1. Record of illustrated species

\begin{tabular}{|c|c|c|c|c|c|}
\hline Taxa & $\begin{array}{l}\text { Plate/ } \\
\text { Figure }\end{array}$ & $\begin{array}{c}\text { Novo } \\
\text { Remanso } \\
\text { Formation } \\
\text { (outcrops) }\end{array}$ & Lithology & $\begin{array}{c}\text { Slide } \\
\text { (number) }\end{array}$ & $\begin{array}{l}\text { England } \\
\text { finder }\end{array}$ \\
\hline Psilatriletes sp. & $1 / 1$ & $\mathrm{X}$ & Pelite & UT-01 & U52-1 \\
\hline Deltoidospora sp. & $1 / 2$ & $\mathrm{X}$ & Pelite & UT-17A & Q55-1 \\
\hline Cyatheacidites sp. & $1 / 3$ & $\mathrm{X}$ & Pelite & UT-17A & $043-1$ \\
\hline Deltoidospora adriennis & $1 / 4$ & $\mathrm{X}$ & Pelite & UT-17A & $\mathrm{J} 56-2$ \\
\hline Cingulatisporites sp. & $1 / 5$ & $\mathrm{X}$ & Pelite & UT-02 & $\mathrm{Z} 45-3$ \\
\hline Magnastriatites grandiosus & $1 / 6$ & $\mathrm{X}$ & Pelite & UT-17B & B51-1 \\
\hline Echitriletes sp. & $1 / 7$ & $\mathrm{X}$ & Pelite & UT-01 & R56 \\
\hline scabratetrilete - not identified & $1 / 8$ & $\mathrm{X}$ & Pelite & UT-01 & D38-1 \\
\hline Polypodiisporites sp. & $1 / 9$ & $\mathrm{X}$ & Pelite & UT-17B & $\mathrm{R} 45$ \\
\hline Verrutriletes sp. & $1 / 10$ & $\mathrm{X}$ & Pelite & UT-01 & F45-1 \\
\hline Polypodiisporites usmensis & $1 / 11$ & $\mathrm{X}$ & Pelite & UT-02 & E54-4 \\
\hline Polypodiaceioisporites potoniei & $1 / 12$ & $\mathrm{X}$ & Pelite & UT-01 & $\mathrm{P} 45-2$ \\
\hline Ephedripites sp. & $2 / 1$ & $\mathrm{X}$ & Pelite & UT-18 & $\mathrm{J} 44$ \\
\hline Inaperturopollenites sp. & $2 / 2$ & $\mathrm{X}$ & Pelite & UT-17A & D42-1 \\
\hline Tricolpites sp. cf. T. reticulatus & $2 / 3$ & $\mathrm{X}$ & Pelite & UT-01 & $\mathrm{P} 47-2$ \\
\hline Scabratricolporites sp. & $2 / 4$ & $\mathrm{X}$ & Pelite & UT-01 & V54-4 \\
\hline Retibrevitricolporites sp. & $2 / 5$ & $\mathrm{X}$ & Pelite & UT-01 & W42-4 \\
\hline Tricolporopollenites edmundii & $2 / 6$ & $\mathrm{X}$ & Pelite & UT-18 & $056-4$ \\
\hline Tricolporopollenites edmundii & $2 / 7$ & $\mathrm{X}$ & Pelite & UT-01 & Q50 \\
\hline Tricolpites sp. & $2 / 8$ & $\mathrm{X}$ & Pelite & UT-17A & $043-1$ \\
\hline Syncolporites poricostatus & $2 / 9$ & $\mathrm{X}$ & Pelite & UT-01 & S41-1 \\
\hline Psilatricolpites sp. & $2 / 10$ & $\mathrm{X}$ & Pelite & UT-17A & N56-1 \\
\hline Striatopollis catatumbus & $2 / 11$ & $\mathrm{X}$ & Pelite & UT-01 & H61-2 \\
\hline Ilexpollenites sp. & $2 / 12$ & $\mathrm{X}$ & Pelite & UT-01 & D46 \\
\hline Ilexpollenites sp. & $2 / 13$ & $\mathrm{X}$ & Pelite & UT-01 & Y38-3 \\
\hline Proteacidites sp. & $2 / 14$ & $\mathrm{X}$ & Pelite & UT-18 & $036-4$ \\
\hline Monoporopollenites annulatus & $2 / 15$ & $\mathrm{X}$ & Pelite & UT-01 & 063-1 \\
\hline Mauritiidites franciscoi var. franciscoi & $2 / 16$ & $\mathrm{X}$ & Pelite & UT-01 & R64 \\
\hline Mauritiidites franciscoi var. franciscoi & $2 / 17$ & $\mathrm{X}$ & Pelite & UT-17A & B $41-3$ \\
\hline Rhoipites sp. & $2 / 18$ & $\mathrm{X}$ & Pelite & UT-02 & J33-1 \\
\hline Malvacipollis spinulosa & $2 / 19$ & $\mathrm{X}$ & Pelite & UT-01 & Q32-4 \\
\hline Psilastephanocolporites cf. P. marinamensis & $2 / 20$ & $\mathrm{X}$ & Pelite & UT-01 & H61-4 \\
\hline Perisyncolporites pokornyi & $2 / 21$ & $\mathrm{X}$ & Pelite & UT-17B & L44 \\
\hline Perisyncolporites pokornyi & $2 / 22$ & $\mathrm{X}$ & Pelite & UT-17A & M43-3 \\
\hline Psilatricolporites sp. & $2 / 23$ & $\mathrm{X}$ & Pelite & UT-02 & Z39-2 \\
\hline Malvacearumpollis estelae & $2 / 24$ & $\mathrm{X}$ & Pelite & UT-01 & Q25-1 \\
\hline
\end{tabular}




\begin{tabular}{|c|c|c|c|c|c|}
\hline Taxa & $\begin{array}{l}\text { Plate/ } \\
\text { Figure }\end{array}$ & $\begin{array}{c}\text { Novo } \\
\text { Remanso } \\
\text { Formation } \\
\text { (outcrops) }\end{array}$ & Lithology & $\begin{array}{c}\text { Slide } \\
\text { (number) }\end{array}$ & $\begin{array}{l}\text { England } \\
\text { finder }\end{array}$ \\
\hline Crototricolpites annemariae & $3 / 1$ & $\mathrm{X}$ & Pelite & UT-02 & W27-1 \\
\hline Crototricolpites annemariae & $3 / 2$ & $\mathrm{X}$ & Pelite & UT-17B & U58-4 \\
\hline Crototricolpites sp. & $3 / 3$ & $\mathrm{X}$ & Pelite & UT-01 & $043-2$ \\
\hline Perfotricolpites digitatus & $3 / 4$ & $\mathrm{X}$ & Pelite & UT-01 & U55-3 \\
\hline Jandufouria sp. & $3 / 5$ & $\mathrm{X}$ & Pelite & UT-02 & E28 \\
\hline Psilastephanoporites tesseroporus & $3 / 6$ & $\mathrm{X}$ & Pelite & UT-01 & $\mathrm{T} 43$ \\
\hline tetracolpate reticulate pollen grain - not identified & $3 / 7$ & $\mathrm{X}$ & Pelite & UT-02 & $\mathrm{J} 60-2$ \\
\hline Bombacacidites baumfalki & $3 / 8$ & $\mathrm{X}$ & Pelite & UT-01 & L33-1 \\
\hline Jandufouria seamrogiformis & $3 / 9$ & $\mathrm{X}$ & Pelite & UT-02 & $028-4$ \\
\hline Jandufouria seamrogiformis & $3 / 10$ & $\mathrm{X}$ & Pelite & UT-01 & H58 \\
\hline Bombacacidites sp. & $3 / 11$ & $\mathrm{X}$ & Pelite & UT-17B & S55-3 \\
\hline Rhoipites romeroi & $3 / 12$ & $\mathrm{X}$ & Pelite & UT-01 & $\mathrm{C} 46-2$ \\
\hline Chomotriletes rubinus & $4 / 1$ & $\mathrm{X}$ & Pelite & UT-02 & W28-2 \\
\hline Chomotriletes circulus & $4 / 2$ & $\mathrm{X}$ & Pelite & UT-01 & $\mathrm{P} 43-3$ \\
\hline Ovoidites sp. cf. O. parvus & $4 / 3$ & $\mathrm{X}$ & Pelite & UT-17B & Y57 \\
\hline Botryococcus braunii & $4 / 4$ & $\mathrm{X}$ & Pelite & UT-17A & L52-1 \\
\hline Ovoidites parvus & $4 / 5$ & $\mathrm{X}$ & Pelite & UT-01 & $\mathrm{H} 46-2$ \\
\hline Ovoidites sp. & $4 / 6$ & $\mathrm{X}$ & Pelite & UT-02 & $\mathrm{S} 40$ \\
\hline Fungi 1 - not identified & $4 / 7$ & $\mathrm{X}$ & Pelite & UT-02 & S39-3 \\
\hline Multicellaesporites sp. & $4 / 8$ & $\mathrm{X}$ & Pelite & UT-17A & $\mathrm{T} 44$ \\
\hline Fungi 2 - not identified & $4 / 9$ & $\mathrm{X}$ & Pelite & UT-17B & F40-2 \\
\hline Scolecodont sp. - not identified & $4 / 10$ & $\mathrm{X}$ & Pelite & UT-01 & F63-4 \\
\hline \multirow{5}{*}{ Barren Samples } & & $\mathrm{X}$ & Fine Sandstone & UT-3 & \\
\hline & & $\mathrm{X}$ & Fine Sandstone & UT-4 & \\
\hline & & $\mathrm{X}$ & Fine Sandstone & UT-12 & \\
\hline & & $\mathrm{X}$ & Fine Sandstone & UT-14 & \\
\hline & & $\mathrm{X}$ & Fine Sandstone & UT-19 & \\
\hline
\end{tabular}

